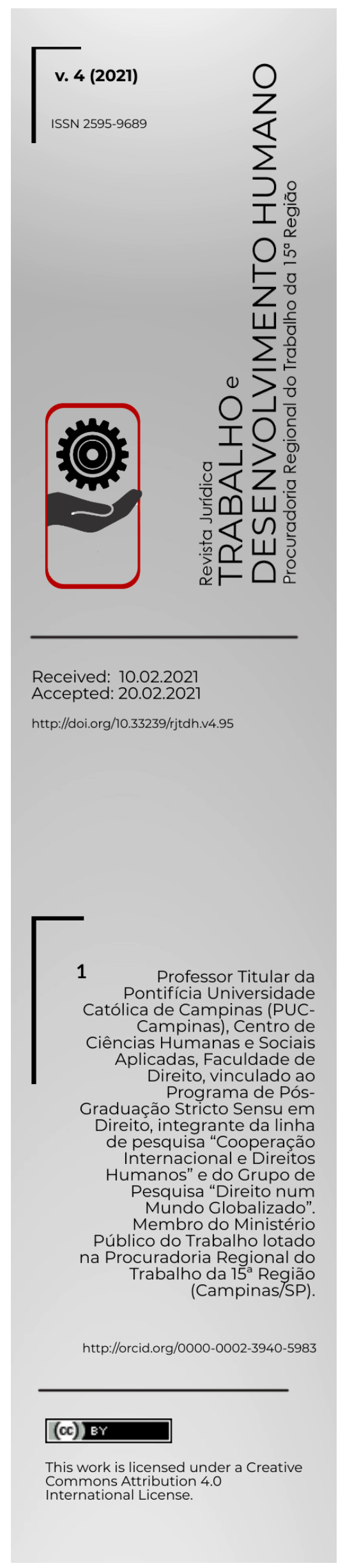

\title{
Conteúdo material e culturalmente inclusivo do Princípio da Dignidade da Pessoa Humana
}

Material and culturally inclusive content of the Principle of the Dignity of the Human Person

Contenido material y culturalmente inclusivo del Principio de la Dignidad de la Persona Humana

Silvio Beltramelli Neto'

\begin{abstract}
RESUMO
Pretende-se, a partir do exame de diferentes abordagens filosóficas da noção de dignidade humana, apresentar os termos de um conteúdo do Princípio da Dignidade da Pessoa Humana que se mostre consentâneo com a realidade da desigualdade material e da opressão cultural que permeiam o modelo societal vigente. Para tanto, foi empregado o método procedimental bibliográfico, tendo-se por ponto de partida a proposta de Daniel Sarmento sobre as funções e componentes do Princípio da Dignidade da Pessoa Humana, sobretudo os componentes do mínimo existencial e do reconhecimento, analisados, neste artigo, à luz de outros autores dos campos do conhecimento filosófico, sociológico e jurídico. Conclui-se que o Princípio da Dignidade da Pessoa Humana exige seja dada máxima proteção aos direitos à igualdade material e ao reconhecimento, o que reclama, necessariamente, a preservação de espaços institucionais deliberativos que assegurem representação plural de todos os grupos econômica e culturalmente vulneráveis.
\end{abstract}

PALAVRAS-CHAVE: Direitos Humanos. Princípio da Dignidade da Pessoa Humana. Mínimo Existencial. Reconhecimento.

\section{ABSTRACT}

It is intended, from the examination of different philosophical approaches to the notion of human dignity, to present the terms of a content of the Principle of the Dignity of the Human Person that is in line with the reality of material inequality and cultural oppression that permeate the prevailing societal model. For this purpose, the bibliographic procedural method was used, having as its starting point Daniel Sarmento's proposal on the functions and components of the Principle of the Dignity of the Human Person, especially the components of the existential minimum and recognition, analyzed, in this article, in the light of other authors in the fields of philosophical, sociological and legal knowledge. It follows that the Dignity of the Human Person Principle requires that maximum protection be given to the rights to material equality and recognition, which necessarily calls for the preservation of institutional deliberative spaces that ensure plural representation of all economically and culturally vulnerable groups.

KEYWORDS: Human Rights. Principle of the Dignity of the Human Person. Existential Minimum. Recognition.

\section{RESUMEN}

Se pretende, a partir del examen de los diferentes enfoques filosóficos de la noción de dignidad humana, presentar los términos de un contenido del Principio de Dignidad de la Persona Humana que esté en consonancia con la realidad de la desigualdad material y la opresión cultural que impregnan el modelo de sociedad actual. Para ello, se utilizó el método procesal bibliográfico, teniendo como punto de partida la propuesta de Daniel Sarmento sobre las funciones y componentes del Principio de la Dignidad de la Persona Humana, especialmente los componentes del mínimo existencial y del reconocimiento, analizados, en este artículo, a la luz de otros autores del ámbito del conocimiento filosófico, sociológico y jurídico. Concluimos que el Principio de la Dignidad de la Persona Humana exige que se protejan al máximo los derechos a la igualdad material y al reconocimiento, lo que exige necesariamente la preservación de espacios institucionales de deliberación que aseguren la representación plural de todos los grupos económica y culturalmente vulnerables.

PALABRAS ClAVE: Derechos humanos. Principio de la Dignidad de la Persona Humana. Mínimo Existencial. Reconocimiento. 
INTRODUÇÃO

Cogita-se que a primeira aparição da dignidade humana em um texto normativo tenha se verificado no preâmbulo de decreto de 1848 , que aboliu a escravidão na França. Ainda antes das Guerras Mundiais, as constituições do México de 1917, de Weimar (Alemanha) e da Finlândia, ambas de 1919, também contemplaram a expressão.

No entanto, no mais das vezes grafada "dignidade da pessoa humana", a dignidade humana multiplicou-se, nos documentos jurídicos internacionais e nacionais, dentro do movimento de afirmação global dos direitos humanos, iniciado após a Segunda Guerra Mundial.

A dignidade humana, assim, materializa-se no ordenamento jurídico internacional e nacional como norma positivada do tipo princípio - o "Princípio da Dignidade da Pessoa Humana" -, com estrutura mais aberta, a desafiar reflexões, no campo da dogmática, sobre a amplitude do seu conteúdo normativo e, por conseguinte, sobre suas possibilidades de aplicação.

A interpretação da história e dos textos normativos tem convergido, em geral, para apontar a proteção da dignidade humana como fundamento dos direitos humanos. Todavia, há de se reconhecer que o conteúdo contemporâneo da dignidade humana, quando tomada como fundamento dos direitos humanos, é devoto de uma construção histórica absolutamente influenciada pelo pensamento filosófico de matriz ocidental, com marcadas origens no pensamento grego clássico e no ideário cristão, embora não seja correto afirmar a originalidade dessas compreensões, mas sim sua ampla disseminação.

Para fins do estudo que se segue, os termos "dignidade humana" e "dignidade da pessoa humana" serão utilizados de modo distinto, empregando-se a primeira para designar a ideia tratada pelos campos não jurídicos do pensamento e reservando-se a última para referências ao princípio positivado em normas jurídicas constitucionais e internacionais, comumente conhecido como "Princípio da Dignidade da Pessoa Humana".

O objetivo deste artigo é, a partir do exame de diferentes abordagens filosóficas da noção de dignidade humana, aprofundar-se nos elementos de um conteúdo do Princípio da Dignidade da Pessoa Humana que se mostre consentâneo com a realidade da desigualdade 
Revista Jurídica Trabalho e Desenvolvimento Humano Procuradoria Regional do Trabalho da 15a Região

material e da opressão cultural que permeiam o modelo societal vigente. Para tanto, foi empregado o método procedimental bibliográfico, tendo-se por ponto de partida a proposta de Daniel Sarmento sobre as funções e componentes do Princípio da Dignidade da Pessoa Humana, sobretudo os componentes do mínimo existencial e do reconhecimento, analisados à luz de outros autores dos campos do conhecimento filosófico, sociológico e jurídico.

\section{Precedentes históricos da noção de dignidade humana}

Do pensamento grego clássico, passando pela doutrina cristã medieval, a noção de dignidade construiu-se com foco na superioridade do ser humano em relação aos demais seres vivos, justificada ora pela razão e livre-arbítrio, ora pela criação divina, ora pela associação de ambos os atributos. Tais construções não incorporaram, todavia, uma ideia de dignidade como critério de tratamento igualitário entre os seres humanos. A igualdade, portanto, não era um elemento do conteúdo da noção pré-moderna de dignidade humana. ${ }^{1}$

Na Antiguidade Clássica, Protágoras, ao vaticinar que "O homem é a medida de todas as coisas, das coisas que são, enquanto são, das coisas que não são, enquanto não são", sumariou a ideia corrente de superioridade do humano sobre os outros seres vivos, o que se pode associar a uma noção de dignidade da espécie humana, compreendida como coletividade. $^{2}$

Todavia, na perspectiva individual, conquanto a racionalidade do ser humano tenha sido exaltada como qualidade distintiva fundamental à busca da verdade e do autoconhecimento, como defendido por Sócrates, a ideia de dignitas comportava gradação (pessoas mais ou menos dignas), porquanto explicava-se pela posição socialmente reconhecida por determinado indivíduo. ${ }^{3}$ Basta recordar que, no contexto da antiguidade helenística, a dignitas dos cidadãos gregos era a chave para a condição de cidadão, atribuída

\footnotetext{
${ }^{1}$ FRIAS, Lincoln; LOPES, Nairo. Considerações sobre o conceito de dignidade humana. Revista Direito GV, v. 11, n. 2, p. 649-670, dez. 2015, p. 654.

2 SARMENTO, Daniel. Dignidade da pessoa humana: conteúdo, trajetórias e metodologia. 2. ed. Belo Horizonte: Fórum, 2020, p. 27-28.

${ }^{3}$ SARLET, Ingo W. Dignidade da pessoa humana e direitos fundamentais na Constituição Federal de 1988.4. ed. Porto Alegre: Livr. do Advogado, 2006, p. 30.
} 
Revista Jurídica Trabalho e Desenvolvimento Humano Procuradoria Regional do Trabalho da 15a Região

apenas a alguns e admitida como fundamento, de um lado, para uma participação seletiva nas deliberações sobre a pólis e, de outro, para a legitimação da escravidão e subjugação dos demais integrantes do círculo familiar (esposa, filhos, etc.). A respeito, não se pode esquecer que Aristóteles, célebre precursor da justiça distributiva e sua máxima "tratar igualmente os iguais e desigualmente os desiguais", aquiesceu com a escravidão, encorpando a noção de vigência de uma desigualdade natural, manifestada na divisão social do trabalho entre seres superiormente capacitados para a liberdade e para a cidadania (também em sentido político) e indivíduos inferiores, destinados ao trabalho forçado. ${ }^{4}$

A dignitas sem igualdade também se fez presente na Roma Antiga, dado que atrelada à posição socialmente distinguida de determinadas pessoas com privilégios morais e materiais em relação aos demais. Conquanto o estoicismo, sobretudo de Cícero, ao preceituar a dignidade como decorrência da razão humana, seja frequentemente lembrado como uma das primeiras propostas universalistas de dignitas $^{5}$, a escravidão também era aceita por aquele filósofo e advogado clássico, que se limitava a condenar excesso de violência cometida contra os escravos. ${ }^{6}$

Na Idade Média, sobressai a compreensão cristã de dignidade humana, calcada na superioridade do ser humano em face das demais criaturas vivas e inanimadas do mundo como resultado da criação por Deus à sua imagem e semelhança. Santo Agostinho exaltara a racionalidade humana como atributo distintivo concedido por obra divina, tendo, todavia, desenvolvido o conceito de "graça divina" enquanto circunstância também oferecida por Deus ao ser humano, mas não a todos, senão apenas a certos eleitos, a quem será conferida a salvação. Já São Tomás de Aquino fez uso da expressão "dignidade humana" como atributo divino que dota o ser humano de liberdade intrínseca à sua natureza, conformada por sua

\footnotetext{
${ }^{4}$ SARMENTO, Daniel. Dignidade da pessoa humana: conteúdo, trajetórias e metodologia. 2. ed. Belo Horizonte: Fórum, 2020, p. 30.

${ }^{5}$ SARLET, Ingo W. Dignidade da pessoa humana e direitos fundamentais na Constituição Federal de 1988.4. ed. Porto Alegre: Livr. do Advogado, 2006, p. 31.

${ }^{6}$ SARMENTO, Daniel. Dignidade da pessoa humana: conteúdo, trajetórias e metodologia. 2. ed. Belo Horizonte: Fórum, 2020, p. 31.
} 
Revista Jurídica Trabalho e Desenvolvimento Humano Procuradoria Regional do Trabalho da 15aㅡ Região

autodeterminação (livre arbítrio), contudo, aquiesceu com a vigência de uma ordem hierárquica entre as pessoas, determinada pela Providência Divina. ${ }^{7}$

A Era Pré-Moderna, portanto, testemunhou propostas de dignidade da espécie humana, mas sem que isso significasse seu reconhecimento e atribuição a todos indivíduos. Faltava o traço da igualdade.

A Idade Moderna, com Pico Della Mirandola e seu "Discurso sobre a Dignidade do Homem", vê a noção de dignidade humana começar a ceder aos impulsos antropocêntricos do movimento renascentista, na medida em que entende o ser humano uma criação de Deus de natureza indefinida e senhor de seu destino, inclusive com o poder de legislar sobre si, em contraste com os outros seres vivos, de natureza definida e absolutamente regidos pelas leis divinas. ${ }^{8}$

O indivíduo, assim, começa a ter sua dignidade humana completamente assentada em seu livre-arbítrio e não propriamente em sua condição de criatura de Deus. Nem por isso, tal ideário traduziu-se em imperativo ético-jurídico de igualação das pessoas para efeitos de direitos e obrigações, independentemente de sua posição ou reconhecimento social, o que apenas viria a ocorrer, séculos adiante, com as proposições jusnaturalistas iluministas, que consolidaram o processo de racionalização e laicização da noção de dignidade humana. É o tempo da dignidade da pessoa humana. ${ }^{9}$

Antes de Kant, porém, cumpre mencionar a contribuição de Samuel Pufendorf à laicização da dignidade humana, na medida em que a descreveu como liberdade de ação de todo ser humano segundo sua razão e preferências, intangível até mesmo pelo monarca. ${ }^{10}$

\footnotetext{
${ }^{7}$ SARLET, Ingo W. Dignidade da pessoa humana e direitos fundamentais na Constituição Federal de 1988.4. ed. Porto Alegre: Livr. do Advogado, 2006, p. 31-32.

${ }^{8}$ SARLET, Ingo W. Dignidade da pessoa humana e direitos fundamentais na Constituição Federal de 1988.4. ed. Porto Alegre: Livr. do Advogado, 2006, p. 32; LAUXEN, Elis Cristina Uhry; BARRETTO, Vicente de Paulo. A (re)construção da ideia de dignidade humana. Revista Quaestio luris, v. 11, n. 1, p. 67-88, 11 jan. 2018 , p. 69.

${ }_{9}^{9}$ SARMENTO, Daniel. Dignidade da pessoa humana: conteúdo, trajetórias e metodologia. 2. ed. Belo Horizonte: Fórum, 2020, p. 28. Como sumaria Maluschke: "Na Antiguidade greco-romana, 'dignidade' era, em primeiro lugar, um termo sócio-político; na Idade Média, aparece como princípio teológico, e isto tanto na perspectiva política (teologia política) quanto no contexto de uma antropologia teológica. Na Idade Moderna, finalmente se faz valer como conceito da ética, e isto particularmente na filosofia de Immanuel Kant" (MALUSCHKE, Günther. A dignidade humana como princípio ético-jurídico. NOMOS - Revista do Curso de Mestrado da UFC, v. 37, n. 1, p. 95-117, jun. 2017, p. 99)

${ }^{10}$ SARLET, Ingo W. Dignidade da pessoa humana e direitos fundamentais na Constituição Federal de 1988.4. ed. Porto Alegre: Livr. do Advogado, 2006, p. 32.
} 
Revista Jurídica Trabalho e Desenvolvimento Humano Procuradoria Regional do Trabalho da 15a Região

Segundo Pufendorf, a dignidade é traço positivo da superioridade do ser humano que atine à sua moralidade, pois é dado às pessoas distinguir entre bem e mal em sua tomada livre de decisão, devendo se comportar, racionalmente, segundo uma norma geral baseada na associação entre dignidade e autoestima: quem se respeita, respeita seu semelhante. ${ }^{11}$

Mas é na filosofia iluminista de Immanuel Kant que a noção de dignidade humana se desgarra por completo de seu veio cristão e propõe-se universal por meio de dois elementos teóricos: a racionalidade como fundamento da existência humana, enquanto finalidade em si, e a enunciação da ideia de imperativos categóricos como comportamentos universalmente válidos e esperados de toda pessoa, em qualquer situação ou espaço.

Em sua célebre obra "Fundamentação da Metafísica dos Costumes", de 1785, Kant consagra a ideia segundo a qual a dignidade humana encontra esteio na racionalidade que distingue o ser humano dos demais seres do mundo, porquanto o capacita a tomar decisões livres sobre seu destino de acordo com suas preferências, portanto, com sua moralidade. Dito de outro modo, o filósofo iluminista explica a dignidade humana a partir da ideia de autodeterminação do indivíduo, conduzida por sua racionalidade, por sua vez influenciada por diretrizes (leis) morais universalmente aceitas, denominadas imperativos categóricos. ${ }^{12}$

Partindo da afirmação de um imperativo categórico (moral) de respeito absoluto e incondicional à autodeterminação dos indivíduos, Kant formula a clássica e ainda extremamente difundida afirmação do ser humano como fim em si mesmo, circunstância que Ihe atribui dignidade ${ }^{13}$. Consagra-se, assim, a máxima moral ${ }^{14}$ universal proibitiva da objetificação ou coisificação de qualquer pessoa.

A dignidade humana kantiana, representativa dos ideais do iluminismo revolucionário do século XVIII, universalizou e, assim, generalizou os direitos humanos, desde uma

\footnotetext{
11 MALUSCHKE, Günther. A dignidade humana como princípio ético-jurídico. NOMOS - Revista do Curso de Mestrado da UFC, v. 37, n. 1, p. 95-117, jun. 2017, p. 100.

12 KANT, Immanuel. Fundamentação da metafísica dos costumes e outros escritos. Trad. Leopoldo Holzbach. São Paulo: Martin Claret, 2005, p. 45.

13 KANT, Immanuel. Fundamentação da metafísica dos costumes e outros escritos. Trad. Leopoldo Holzbach. São Paulo: Martin Claret, 2005, p. 65.

14 “Ora, a moralidade é a única condição capaz de fazer que um ser racional seja um fim em si, pois só mediante ela é possível ser um membro legislador no reino dos fins. Pelo que, a moralidade, bem como a humanidade, enquanto capaz de moralidade, são as únicas coisas que possuem dignidade" (KANT, Immanuel. Fundamentação da metafísica dos costumes e outros escritos. Trad. Leopoldo Holzbach. São Paulo: Martin Claret, 2005, p. 65).
}

BeltramelLi NETO, Silvio. Conteúdo material e culturalmente inclusivo do Princípio da Dignidade da Pessoa Humana. Revista Jurídica Trabalho e Desenvolvimento Humano, Campinas, v. 4, p. 1-42, 2021. 
Revista Jurídica Trabalho e Desenvolvimento Humano Procuradoria Regional do Trabalho da 15a Região

perspectiva jusnaturalista de viés igualitário, ao preceituar que todas as pessoas ostentam dignidade, independentemente de sua posição social ou filiação religiosa. Trata-se da dignidade como consectário da razão humana e de sua capacidade de autodeterminação. Tal ideário logo se afirmou no campo político, adotado pelo liberalismo, e, consequentemente, no campo jurídico, sobretudo por obra da Declaração de Independência dos Estados Unidos da América (1776), sucedida da Constituição dos EUA (1787), bem como da Declaração do Homem e do Cidadão da França (1789), e vige como grande referencial filosófico, político e jurídico até os dias atuais. ${ }^{15}$

Conquanto perene, a visão kantiana vem experimentando, ao longo dos séculos, relevantes críticas, as quais, em geral, acusam-lhe de excessiva abstração do ser humano, do exercício de sua racionalidade, da vigência e observância de imperativos categóricos universalmente aceitos e, por conseguinte, da concepção natural e igualitária de dignidade humana.

Hegel contestou a naturalização da dignidade humana, ao condicioná-la, no campo da realidade dos indivíduos, ao reconhecimento e respeito pela sociedade que o circunda. A dignidade humana e a igualdade, neste passo, para Hegel, são resultados do campo prático das relações humanas ${ }^{16}$. Por conseguinte, diferentemente de Kant, Hegel não atrela a dignidade à racionalidade, tampouco reconhece sua inerência à condição de humanidade, senão apenas admite que dignidade é prerrogativa ou privilégio daquele que se vê reconhecido pela sociedade em que vive como cidadão.

Inicialmente um discípulo de Hegel, Karl Marx e seu materialismo histórico - que viria torná-lo um dissidente opositor do idealismo hegeliano ${ }^{17}$ - refutaram, desde sempre, a

\footnotetext{
${ }^{15}$ No Brasil, proeminentes análises sobre o princípio jurídico da dignidade da pessoa humana ainda são realizadas sob o prisma kantiano, com frequente eco na jurisprudência nacional, sobretudo do Supremo Tribunal Federal. A respeito, cf. SILVA, José Afonso da. A dignidade da pessoa humana com valor supremo da democracia. Revista de direito administrativo, v. 212, p. 89-94, 1998; BARCELLOS, Ana Paula de. Normatividade dos princípios e o princípio da dignidade da pessoa humana na Constituição de 1988. Revista de direito administrativo, v. 221, p. 159-188, 2000; SARLET, Ingo W. Notas sobre a dignidade da pessoa humana na jurisprudência do STF. In SARMENTO, Daniel; SARLET, Ingo W. (Coord.). Direitos Fundamentais no Supremo Tribunal Federal: balanço e crítica. Rio de Janeiro: Lumen Juris, 2011.

${ }^{16}$ HEGEL, G. W. Princípios da Filosofia do Direito. Trad. Orlando Vitorino. São Paulo: Martins Fontes, 1997, p. XXXIV.

17 "Em completa oposição à filosofia alemã, a qual desce do céu à terra, aqui sobe-se da terra ao céu" (MARX, Karl; ENGELS, Friedrich. A ideologia alemã. Trad. Álvaro Pina. São Paulo: Expressão Popular, 2009, p. 31).
} 
Revista Jurídica Trabalho e Desenvolvimento Humano Procuradoria Regional do Trabalho da 15aㅡ Região

admissão de uma dignidade de cunho igualitário derivada da condição humana, incompatível com as opressões sociais reais concretizadas em subjugação de pessoas à sanha do capital, tendo por consequência o aprofundamento das desigualdades materiais, representado pela tensão entre quem detém meios de produção e aqueles que têm na venda da força de trabalho a única alternativa para a sobrevivência.

Na visão de Marx, a livre autodeterminação do indivíduo pela sua razão é uma ilusão, porquanto o exercício da razão é diretamente condicionado pelas relações materiais (concretas) que medeiam as ações e pensamentos desse indivíduo, tendo asseverado que "a consciência [das Bewusstein] nunca pode ser outra coisa senão o ser consciente [das bewusste Sein], e o ser dos homens é o seu processo real de vida"18. Daí que "não é a consciência que determina a vida, é a vida que determina a consciência". ${ }^{19}$ Por conseguinte, para Marx, a ideia kantiana de dignidade humana intensifica a autopercepção individualista das pessoas, que interessa à manutenção da desigualdade econômica capitalista, ao tempo em que também obstaculiza a conscientização do ser humano enquanto ser social, necessária para a superação da desigualdade material imposta pelo sistema capitalista.

Outro ferrenho crítico da concepção da igualdade humana como atributo natural da dignidade foi Friedrich Nietzsche, para quem, em suma, o cânone liberal de igualdade não passa de discurso político, transmutado em paradigma moral, tóxico e vazio, porque busca nivelar e aniquilar as diferenças que são próprias de cada individualidade, ao mesmo tempo em que invisibiliza as condições desiguais de vida dos seres humanos. ${ }^{20}$

\footnotetext{
18 MARX, Karl; ENGELS, Friedrich. A ideologia alemã. Trad. Álvaro Pina. São Paulo: Expressão Popular, 2009

${ }^{19}$ MARX, Karl; ENGELS, Friedrich. A ideologia alemã. Trad. Álvaro Pina. São Paulo: Expressão Popular, 2009, p. 32.

${ }^{20}$ NIETZSCHE, Friedrich. Escritos sobre Política. Trad. Noéli Correia de Melo Sobrinho. São Paulo, SP: Loyola, 2007. Repetidas e ácidas críticas a diversas formulações kantianas são encontradas em NIETZSCHE, Friedrich. Genealogia da moral: uma polêmica. Trad. Paulo César de Souza. São Paulo: Companhia das Letras, 2009. Para um exame das críticas de Nietzsche à igualdade em termos liberais e sua disseminação no campo da educação, cf. MENDONÇA, Samuel. Objeções à igualdade e à democracia: a diferença como base da educação aristocrática. ETD - Educação Temática Digital, v. 14, n. 1, p. 332-350, 2012.
} 
Revista Jurídica Trabalho e Desenvolvimento Humano Procuradoria Regional do Trabalho da 15a Região

2. Ideia versus concreto: sentido amplo e complexo da dignidade humana

Entre os séculos XIX e XX, ao tempo em que o capitalismo foi se estabelecendo como um modo societal, não apenas atinente às possibilidades econômicas, mas verdadeiramente respeitante à vida em sociedade, com seus imperativos de consumo, dinâmicas de acumulação patrimonial e lógicas geopolíticas expansionistas e colonialistas, a percepção ideal da igualdade natural entre os seres humanos foi se desvanecendo frente à crueza dos fatos, à medida em que a desigualdade social crescia e se aprofundava. A escravidão africana colonial do século XIX, o avanço da exploração da mão de obra assalariada pós Segunda Revolução Industrial, os regimes políticos autocráticos e os genocídios perpetrados nas duas Guerras Mundiais do século XX não foram evitados pelas declarações e constituições contemplativas das liberdades individuais, da autodeterminação pessoal e da igualdade formal dos seres humanos.

O descumprimento da promessa liberal moderna de preservação da autodeterminação e da igualdade enquanto decorrência natural da razão humana ${ }^{21}$ desvelou a necessidade de reconstrução do conteúdo da dignidade humana, a partir da consideração de sua concretude, ou seja, de suas condições materiais de vivência e sobrevivência, como reivindicado, sob distintas propostas, pelas correntes marxista, socialista utópica, anarquista e até da doutrina social da Igreja Católica. Isso porque a realidade impõe a constatação, segundo a qual, a autodeterminação está completamente adstrita às possibilidades materiais de seu exercício, diante do descompasso entre faculdade ideal do uso da razão e condições e oportunidades reais de fazê-lo.

Nessa perspectiva, o fenômeno da desigualdade social, que exclui, ainda que em diferentes níveis, seres humanos da condição de plena autodeterminação, não pode mais ser alijado da perquirição sobre o conteúdo da dignidade humana. E o fenômeno da exclusão

\footnotetext{
${ }^{21}$ Boaventura de Sousa Santos afirma que a modernidade teria anunciado e não cumprido duas importantes promessas: a solução dos problemas de distribuição, os quais levam populações inteiras à privação de condições mínimas de sobrevivência, e a "democratização política do sistema democrático", entendida esta como a inserção livre das classes populares no sistema político. Sustenta que modernidade ocidental legou uma realidade de fragmentação extrema, que tem como faceta mais desumana o aprofundamento da exclusão social (SANTOS, Boaventura de Sousa. Pela mão de Alice: o social e o político na pós-modernidade. 14. ed. São Paulo: Cortez, 2013, p. 127).
} 
Revista Jurídica Trabalho e Desenvolvimento Humano Procuradoria Regional do Trabalho da 15a Região

social é multifacetado, na medida em que se verifica segundo distintos critérios ou circunstâncias agregadoras de pessoas em determinadas condições de insegurança. Dito de outro modo, a exclusão social subjuga diferentes grupos vulneráveis.

Eduardo Bittar relembra a publicação científica "Atlas da exclusão social no Brasil" de 2003, que revela a passagem de uma velha a uma nova exclusão social, mais ampla, que propiciou a "expansão das populações atingidas e dos contingentes humanos envolvidos em situações limítrofes entre vida e morte, dignidade e indignidade, cidadania e exclusão completa". A velha exclusão se revela pelos baixos níveis de renda e escolaridade que assolam, notadamente, negros, mulheres, migrantes, analfabetos e famílias mais numerosas. Já a nova exclusão social se sobrepõe à velha e amplia as populações socialmente vulneráveis, assim como multiplica as formas de manifestação da exclusão, alcançando as esferas cultural, econômica e política, de modo a atingir novos segmentos sociais até então relativamente preservados do processo excludente, a exemplo de jovens com elevada escolaridade, pessoas com mais de 40 anos, homens negros e famílias monoparentais, em face de quem o desemprego e a precarização dos postos de trabalho disponíveis afirmam-se como novos instrumentos excludentes. ${ }^{22}$

Boaventura De Sousa Santos distingue desigualdade e exclusão social, embora as aponte como dois tipos ideais modernos e concomitantes, que se estabelecem de modo permanente, a partir da convergência entre modernidade e capitalismo, estabelecida no século XIX. Segundo o sociólogo português, a desigualdade não é exatamente excludente, porque existe em um quadro relacional e hierarquizado de privilégios, cujo critério de diferenciação é essencialmente econômico. O princípio que rege a desigualdade é o da integração social, pois pessoas estão inseridas em um contexto de fruição de direitos, ainda que em distintas intensidades. Já a exclusão social rege-se pelo princípio da segregação, porquanto o excluído encontra-se fora do quadrante em que há apenas desigualdade, sendo alijado da possibilidade de fruir direitos e de reivindicá-los. O critério excludente vai além do

${ }^{22}$ CAMPOS, André de. et. al. Atlas da exclusão social no Brasil, volume 2: dinâmica e manifestação territorial. São Paulo: Cortez: 2003, p. 43 e 49; BITTAR, Eduardo C. B. Ética, Cidadania e Constituição: o direito à dignidade e à condição humana. Revista Brasileira de Direito Constitucional, v. 8, n. 1, p. 125-155-155, 31 dez. 2006, p. 128. 
Revista Jurídica Trabalho e Desenvolvimento Humano Procuradoria Regional do Trabalho da 15a Região

aspecto econômico, alcançando atributos socioculturais interseccionais como gênero, raça, sexualidade, crença religiosa, etnia, nacionalidade, deficiência física ou mental, ficha criminal etc. ${ }^{23}$

O sofrimento concreto impingido a corpos humanos pelas dominações e opressões interseccionais infla as críticas mais ferozes contra o valor intrínseco do ser humano e a autonomia enquanto designativos únicos da dignidade humana. No marco do pensamento decolonial, critica-se a atual e disseminada reprodução desse conceito pelos chamados (neo)kantianos, no campo jurídico da atualidade, atribuindo-lhe manutenção daquelas mesmas opressões, que permanecem operantes nas sociedades mais desiguais e excludentes, notadamente nos países em que, a despeito do formal reconhecimento de sua autodeterminação, se verifica a perpetuação de dinâmicas coloniais econômicas, políticas e culturais. ${ }^{24}$

É importante perceber que a complexa e multifacetada chaga da exclusão social, inevitavelmente, conduz sua abordagem à esfera da política institucional e, por conseguinte, da democracia. ${ }^{25}$

Adverte Aieta que na busca por uma definição etimológica de democracia, há que considerar que essa expressão admite exame sob duas perspectivas, quais sejam, uma descritiva (analítica) e outra prescritiva (axiológica). Nesta linha, a distinção entre democracia direta (Grécia clássica) e democracia representativa ("moderna") e suas formas de operação pertencem à perspectiva descritiva, enquanto os modelos democráticos liberal e socialista comportam indagação dentro da perspectiva prescritiva. ${ }^{26}$

A análise descritiva da democracia representativa como "forma de governo" pode ser atribuída a Heródoto, ao tratar do sorteio de "magistrados" como forma de nomeação de

\footnotetext{
${ }^{23}$ SANTOS, Boaventura de Sousa. A gramática do tempo: para uma nova cultura política. 2. ed. Porto: Edições Afrontamento, 2010.

${ }^{24}$ GOMES, Camilla de Magalhães. Os sujeitos do performativo jurídico - relendo a dignidade da pessoa humana nos marcos de gênero e raça. Revista Direito e Práxis, v. 10, n. 2, p. 871-905, jun. 2019.

${ }^{25}$ BELTRAMELLI NETO, Silvio. Exclusão social, regulação do trabalho e crise do sindicalismo nas perspectivas crítica e utópica de Boaventura de Sousa Santos. Revista Direito e Práxis, v. 11, n. 3, p. 1815-1844, set. 2020; BELTRAMELLI NETO, Silvio; BONAMIM, Isadora Rezende; VOLTANI, Julia de Carvalho. Trabalho Decente segundo a OIT: uma concepção democrática? Análise crítica à luz da teoria do contrato social. Revista Eletrônica do Curso de Direito da UFSM, v. 14, n. 1, p. 1-36, 6 maio 2019.

${ }^{26}$ AIETA, Vânia S. Democracia. In: BARRETO, Vicente de P. (Coord.). Dicionário de filosofia do direito. São Leopoldo/Rio de Janeiro: Editora Unisinos; Livraria Editora Renovar, 2009, p. 191-192.
} 
Revista Jurídica Trabalho e Desenvolvimento Humano Procuradoria Regional do Trabalho da 15a Região

grupo designado para a tomada de decisão, no exercício da representação do povo. Todavia, coube a Rousseau categorizar as formas de governo ${ }^{27}$, tendo-o feito sob inspiração solidarista subjacente à noção de Contrato Social (ou Pacto Social).

O Contrato Social é, antes de tudo, um ato de associação orientado à autopreservação, pois a vida em sociedade é, prima facie, predatória ao ser humano. Na impossibilidade de que novas forças "extra-humanas" reguladoras sejam criadas, impende a agregação das forças de cada indivíduo, a resultar uma soma harmônica de forças dirigidas. Busca-se, assim, um sistema de organização social "que defenda e proteja com toda a força comum a pessoa e os bens de cada sócio, e pela qual, unindo-se cada um a todos, não obedeça, todavia, senão a si mesmo e que fique tão livre como antes". ${ }^{28}$

O traço solidarista e essencialmente inclusivo do Contrato Social evidencia-se na enunciação que Rousseau empregou para definir a essência do Pacto idealizado: “Cada um de nós põe em comum sua pessoa e todo o seu poder sobre a suprema direção da vontade geral, e recebemos enquanto corpo cada membro como parte indivisível do todo". Segue-se que tal associação enseja um "corpo moral e coletivo", produto da soma dos interesses comuns de todas as pessoas que o compõe, por isso que corpo coletivo (Soberano) e as individualidades jamais poderão ter, por princípio, interesses colidentes. ${ }^{29}$

Importa notar que o Contrato Social, segundo o seu autor, não é produto da renúncia à liberdade, como em Hobbes, senão a única maneira de maximizá-la na vida em sociedade ${ }^{30}$. O Soberano é, por definição, o porta-voz da vontade geral, a qual não se confunde com a vontade de todos, embora resulte de sua média ${ }^{31}$. A primeira só compreende o interesse comum e, por isso, tão somente põe-se ao proveito do bem comum; a última, de seu turno, não passa de uma soma de vontades particulares. Já o Governo atua por delegação do Soberano, podendo ser exercido por todos os indivíduos (democracia no sentido grego clássico), por uma parcela deles (aristocracia) ou a apenas uma pessoa (monarquia).

\footnotetext{
${ }^{27}$ AIETA, Vânia S. Democracia. In: BARRETO, Vicente de P. (Coord.). Dicionário de filosofia do direito. São Leopoldo/Rio de Janeiro: Editora Unisinos; Livraria Editora Renovar, 2009, p. 191.

${ }^{28}$ ROUSSEAU, Jean-Jaques. Do contrato social. Trad. Pietro Nassetti. São Paulo: Martin Claret, 2004, p. 31.

${ }^{29}$ ROUSSEAU, Jean-Jaques. Do contrato social. Trad. Pietro Nassetti. São Paulo: Martin Claret, 2004, p. 31-33.

${ }^{30}$ SANTOS, Boaventura de Sousa. A crítica da razão indolente: contra o desperdício da experiência. 2 ed. Porto: Edições Afrontamento, 2002, p. 121.

${ }^{31}$ ROUSSEAU, Jean-Jaques. Do contrato social. Trad. Pietro Nassetti. São Paulo: Martin Claret, 2004, p. 41.
} 
Revista Jurídica Trabalho e Desenvolvimento Humano Procuradoria Regional do Trabalho da 15aㅡ Região

Partindo das premissas rousseaunianas para desenvolver seu pensamento, Boaventura de Sousa Santos examina, a miúde, a questão da exclusão social sob a perspectiva da democracia. Inicia afirmando que a regulação social se assenta em 3 (três) princípios: do Estado, do Mercado e da Comunidade. ${ }^{32}$ A associação da modernidade ocidental com o capitalismo consagrou a ascensão do princípio do Mercado sobre os demais, em um processo gradual que se confunde com o próprio processo de transformação e desenvolvimento do capitalismo como padrão societal.

O princípio da Comunidade, tal como acatado por Boaventura, é lastreado na teoria do Contrato Social de Rousseau, fundada na obrigação vertical cidadão-Estado, típica do modelo liberal, mas assenta-se em uma obrigação horizontal cidadão-cidadão, fundante de uma associação política participativa, que exige, para além da igualdade formal, a igualdade substancial ${ }^{33}$, inadmitindo, portanto, a exclusão social.

Lançando luzes sobre a contemporaneidade, Boaventura denuncia a crise atual do Contrato Social, dado que a coesão subjacente à vontade geral desvaneceu-se, ante a perda da centralidade do Estado e do direito estatal como artífices da regulação face à instantaneidade dos interesses do mercado financeiro globalizado, que impulsiona um tempo de contratualização, não de cunho social, mas de natureza eminentemente liberal-individual e, por isso, efêmera, conformando uma espécie de "Contrato Social Neoliberal" ou "Contrato Social Pós-Moderno Leonino", onde predomina a exclusão social sobre os processos inclusivos. ${ }^{34}$

Pontualmente apoiado em Kant, aduz Boaventura, que a noção moderna de democracia, ao limitá-la ao direito de voto, é reducionista e perigosamente liberal, portanto, dissonante do comunitarismo rousseauniano, na medida que o governo exercido pelos representantes eleitos deve fazer coincidir a vontade coletiva dos particulares com a vontade

\footnotetext{
32 SANTOS, Boaventura de Sousa. A crítica da razão indolente: contra o desperdício da experiência. 2 ed. Porto: Edições Afrontamento, 2002, p. 122; SANTOS, Boaventura de Sousa. Do pós-moderno ao pós-colonial. E para além de um e de outro. Travessias, n. 6/7, p. 15-36, 2008, p. 21.

${ }^{33}$ SANTOS, Boaventura de Sousa. Pela mão de Alice: o social e o político na pós-modernidade. 14. ed. São Paulo: Cortez, 2013, p. 228.

${ }^{34}$ SANTOS, Boaventura de Sousa, A gramática do tempo: para uma nova cultura política. 2. ed. Porto: Edições Afrontamento, 2010, p. 301-304.
} 
Revista Jurídica Trabalho e Desenvolvimento Humano Procuradoria Regional do Trabalho da 15a Região

geral, que, por definição, conforma-se pela média da vontade de todos e não apenas da maioria.

Segundo a teoria liberal predominante, a sociedade civil está baseada na igualdade plena de exercício de liberdade, autonomia e interesses de todos os indivíduos, ocultando a desigualdade material inerente ao capitalismo, que limita a própria formação da vontade individual, nos espaços públicos e privados de exercício da cidadania e do trabalho. ${ }^{35}$ Tal ocultação favorece a percepção ilusória de que a democracia se perfaz, integralmente, com a faculdade do voto, escondendo as relações de poder e dominação que fazem dissociar-se as vontades de Soberano e Governo.

A insuficiência da gestão democrática da sociedade, nos moldes atuais, torna esse sistema político conveniente ao capitalismo que faz sucumbir Estado e Comunidade, abrindose as portas para a disseminação do maior risco advindo da crise do Contrato Social, o fenômeno denominado por Boaventura de Fascismo Social. Sua diferença para o Fascismo dos anos trinta e quarenta do século XX reside no fato de não designar apenas um regime político, mas um "regime social e civilizacional". ${ }^{36}$ Neste contexto, o fascismo social eleva a níveis altíssimos a discricionariedade (ou o poder de veto) dos socialmente mais poderosos sobre as chances de vida dos excluídos e dos mal posicionados na escala da desigualdade, minando, como nunca visto, a regra formal da igualdade. ${ }^{37}$

A prevalência do Mercado sobre o Estado e a Comunidade e a crise do Contrato Social aprofundaram e conferiram novos contornos a um tipo de divisão social perceptível desde o século XVI, denominada por Boaventura de divisão entre relações "metropolitanas" e "coloniais", separadas pela "linha abissal". As relações sociais metropolitanas perfazem-se dentro da tensão regulação versus emancipação e nelas a todo indivíduo se atribui algum direito e algum tipo de oportunidade de realização pessoal. Já as relações sociais coloniais vivem sob a dualidade violência versus apropriação e contemplam a mais intensa exclusão

\footnotetext{
${ }^{35}$ SANTOS, Boaventura de Sousa. Pela mão de Alice: o social e o político na pós-modernidade. 14. ed. São Paulo: Cortez, 2013, p. 228.

${ }^{36}$ SANTOS, Boaventura de Sousa. A gramática do tempo: para uma nova cultura política, 2. ed. Porto: Edições Afrontamento, 2010, p. 310-313.

37 SANTOS, Boaventura de Sousa. The resilience of abyssal exclusions in our societies: toward a post-abyssal law. Tilburg Law Review, v. 22, n. 1-2, 2017, p. 237-258.
} 
Revista Jurídica Trabalho e Desenvolvimento Humano Procuradoria Regional do Trabalho da 15a Região

social de pessoas absolutamente desprovidas de direitos realisticamente reivindicáveis, embora até possam ser formalmente reconhecidos. Antes perceptíveis geograficamente, ao tempo do colonialismo histórico (norte/sul), a linha abissal, hoje, perdeu o referencial geográfico, na medida que relações metropolitanas e coloniais convivem em espaços mais reduzidos, como dentro das divisas de países centrais ou mesmo no interior de cidades. ${ }^{38}$

O sociólogo português identifica seis modos de produção da prática social, todos cindidos pela linha abissal e a cada um correspondendo uma forma de poder específica: espaço doméstico (poder do patriarcado), espaço da produção (poder da exploração e da "natureza capitalista"), espaço do mercado (poder do fetichismo das mercadorias), espaço da comunidade (poder da diferenciação desigual), espaço da cidadania (poder da dominação) e o espaço mundial (poder da troca desigual) ${ }^{39}$.

Diante desse cenário, Boaventura propõe uma nova teoria da democracia, que reclama a urgência da democratização de todos os espaços cindidos pela linha abissal excludente ${ }^{40}$, observado o sentido solidarista rousseauniano de asseguramento de participação deliberativa a todos os grupos socialmente excluídos e vulneráveis à desigualdade social por qualquer circunstância ou critério, ainda que quaisquer desses grupos não represente maioria quantitativa em determinado ambiente político-institucional. Uma democracia, portanto, inclusiva que, por isso, jamais poderá ser reduzida ao "governo da maioria" como paradigma tanto para políticas de governo quanto para produção e aplicação de leis.

Rousseau e Boaventura evidenciam que igualdade no concreto só admite ser vislumbrada em um ambiente democrático, que assegure participação ativa e consideração permanente dos interesses de todos os indivíduos, mas, sobretudo, dos desvalidos e ultrajados pela desigualdade e pela exclusão social. No mundo atual, contudo, ambientes assim vão se mostrando cada vez mais implausíveis, à vista da perpetuação do ideário neoliberal de ampla concorrência individual, patrocinada pelo Estado e introjetada pelas subjetividades - inclusive dos excluídos - , onde prevalece o radical individualismo sobre a

\footnotetext{
${ }^{38}$ SANTOS, Boaventura de Sousa. The resilience of abyssal exclusions in our societies: toward a post-abyssal law. Tilburg Law Review, v. 22, n. 1-2, 2017, p. 237-258, p. 251 e 254.

${ }^{39}$ SANTOS, Boaventura de Sousa. A crítica da razão indolente: contra o desperdício da experiência. 2 ed. Porto: Edições Afrontamento, 2002, p. 254.

${ }^{40}$ SANTOS, Boaventura de Sousa. Pela mão de Alice: o social e o político na pós-modernidade, cit., p. 270-271.
} 
Revista Jurídica Trabalho e Desenvolvimento Humano Procuradoria Regional do Trabalho da 15a Região

percepção da solidariedade social. Valendo-se da obra de Ulrich Beck, Pierre Dardot e Christian Laval exclamam a destruição, sob o ideário neoliberal, da "dimensão coletiva da existência", porquanto "assistimos a uma individualização radical que faz com que todas as formas de crise social sejam percebidas como crises individuais, todas as desigualdades sejam atribuídas a um responsável individual". ${ }^{41}$

A concretude da desigualdade e da exclusão social exigem, portanto, uma noção de dignidade humana cujo conteúdo as considere em todas as suas causas e dimensões individuais e coletivas, para que assim (e só assim) possa refletir, de modo adequado, o caráter universalizante entrevisto idealmente por Kant, sem deixar de contemplar a viabilização das condições materiais (concretas) para que cada indivíduo vivencie, de modo livre e pleno, suas singularidades, de acordo com suas preferências.

Impulsionado por reflexões sobre o combate à fome e à miséria como manifestações mais radicais da exclusão social, o economista e filósofo indiano Amartya Sen propôs, com ampla aceitação nos meios acadêmicos e de organizações internacionais de direitos humanos, como ONU e OIT, a ideia de "Desenvolvimento Humano" como norte para o enfrentamento da exclusão social e suas manifestações mais cruéis: a fome e a miséria. Desenvolvimento Humano, nesse contexto, é entendido como a busca da ampliação das capacidades das pessoas.

Sen formula uma teoria própria das capacidades (capability approach), a partir da retomada de inspiração aristotélica da associação entre ética e economia. A teoria das capacidades de Sen preceitua que o desenvolvimento de um indivíduo é resultado direto da conjugação de suas capacidades, entendida capacidade (capability) como "a liberdade substantiva de realizar combinações alternativas de funcionamentos (ou, menos formalmente, a liberdade para ter estilos de vida diversos)". Os citados "funcionamentos" representam as diversas coisas que uma pessoa pode desejar fazer ou ser. O conjunto de capacidades pode ser delimitado pelo leque mais restrito ou mais amplo de oportunidades de aquisição de distintos funcionamentos, ou seja, de bens e caminhos que, por livre decisão da

\footnotetext{
${ }^{41}$ DARDOT, Pierre; LAVAL, Christian. A nova razão do mundo: ensaio sobre a sociedade neoliberal. trad. Mariana Echalar. São Paulo: Boitempo, 2016, p. 348.
}

BeltramelLi NETO, Silvio. Conteúdo material e culturalmente inclusivo do Princípio da Dignidade da Pessoa Humana. Revista Jurídica Trabalho e Desenvolvimento Humano, Campinas, v. 4, p. 1-42, 2021. 
Revista Jurídica Trabalho e Desenvolvimento Humano Procuradoria Regional do Trabalho da 15a Região

própria pessoa ("agência”), representem meios para seu bem-estar segundo suas preferências pessoais. $^{42}$

Perceba-se que, no horizonte teórico seniano, o exercício dos funcionamentos, em um contexto mais ou menos limitado das capacidades, não tem no fator econômico sua única influência, mas admite outras circunstâncias, como é o caso, no plano individual estrito, de deficiência física ou mental, ou, ainda, no plano individual afetado por condições sociais, de adoecimentos evitáveis, déficit formação educacional e discriminações diversas (gênero, raça, etnia, etc.). Ademais, o avanço coletivo das capacidades individuais, diz Sen, depende da preservação de um ambiente político democrático, que dê visibilidade e atenção às demandas das pessoas com severas limitações em suas capacidades, ou seja, os socialmente excluídos. ${ }^{43}$

Face às reflexões apresentadas, uma noção de dignidade humana consentânea com propósitos de salvaguarda da existência humana em termos igualitários não pode se limitar a uma compreensão que naturaliza a autodeterminação e a igualdade como atributos da razão humana. O conteúdo da dignidade humana é muito mais complexo e exige que autodeterminação e igualdade sejam percebidas e contempladas à luz da concretude da vida, por sua vez indissociável das condições materiais em que cada pessoa está imersa e do que isso representa enquanto limites e oportunidades para que, livremente, seja quem deseja ser.

A amplitude e a complexidade do conteúdo da dignidade humana, inevitavelmente, oferecem desafios hermenêuticos à sua expressão jurídica e, em verdade, é preciso admitir que as manifestações jurisprudenciais pelo mundo e, notadamente, no Brasil, não ressoam o quanto aqui proposto, no mais das vezes encontrando-se interpretações casuísticas, sem que se possa entrever esforço jurisdicional na direção de uma mínima delimitação conceitual da questão.

\footnotetext{
42 SEN, Amartya. Sobre ética e economia. Trad. Laura Teixeira Motta. São Paulo: Companhia das Letras, 1999, p. 18-19 e 56-60; SEN, Amartya. Desenvolvimento como liberdade. Trad. Laura Teixeira Motta. São Paulo: Companhia das Letras, 2010, p. 105.

43 SEN, Amartya. Desenvolvimento como liberdade. Trad. Laura Teixeira Motta. São Paulo: Companhia das Letras, 2010, p. 16-53.
} 
Revista Jurídica Trabalho e Desenvolvimento Humano Procuradoria Regional do Trabalho da 15a Região

\section{Conteúdo normativo do Princípio da Dignidade da Pessoa Humana}

A compressão da dignidade humana no plano concreto da existência não parece se conformar com um conceito atemporal. É que as condições materiais da existência humana se estabelecem de modo dinâmico, no curso da História. A sociedade antiga se estabeleceu sob pressupostos éticos, políticos e econômicos distintos dos da sociedade feudal e essa, de seu turno, apresentou uma conformação totalmente diferente do perfil societal liberal capitalista em relação àqueles mesmos três pressupostos.

Admitir a historicidade da dignidade humana provoca desconforto e incompreensão na comunidade jurídica, sempre ávida por categorias, institutos e conceitos hermeticamente delimitados, o que ajuda a propiciar, de um lado, uma aversão - que, no limite, chega à negação - da normatividade da dignidade da pessoa humana, a despeito da expressa previsão constitucional e internacional; e, de outro, falta de rigor metodológico na aplicação desse princípio jurídico a casos concretos, dando ensejo à sua banalização.

Melhor seria se, reconhecida a historicidade da dignidade humana, juristas da academia e da práxis assumissem, em sua totalidade e dentro da institucionalidade vigente, a missão da construção dialógica de um sentido normativo para o Princípio da Dignidade da Pessoa Humana que, longe de reclamar um conceito pronto e acabado, necessita, em verdade, de consenso metodologicamente acessível e aplicável à casuística sobre as funções que aquele princípio cumpre em determinada ordem jurídica, bem como sobre os elementos da existência humana que não podem estar à margem de sua proteção, para o quê as condições de determinada quadra histórica hão de ser consideradas.

A chave, portanto, para a delimitação do conteúdo do princípio jurídico da dignidade da pessoa humana está em perscrutar as razões históricas de sua positivação e, com isso, definir suas funções e seu âmbito de proteção e, então, diretrizes metodológicas para sua aplicação a casos concretos. Variadas propostas para cada uma dessas questões encontramse disponíveis no plano acadêmico e algumas poucas no plano jurisdicional, sobretudo comparado (de outros países).

Aqui interessa cumprir este itinerário sob o ponto de vista da ordem jurídica brasileira, composta por normas nacionais (sobretudo constitucionais) e internacionais incorporadas de 
Revista Jurídica Trabalho e Desenvolvimento Humano Procuradoria Regional do Trabalho da 15a Região

direitos humanos, tomada no contexto social, político e econômico do Brasil e alinhada com a percepção encampada acima sobre a amplitude de uma noção de dignidade humana atenta à concretude do ser humano.

A profunda e rigorosa pesquisa realizada por Daniel Sarmento, publicada sob o título “Dignidade da Pessoa Humana: conteúdo, trajetórias e metodologia”, atende a esse critério, pois, recusando limitar-se à visão ideal e naturalista da dignidade humana, examina, com detalhes, seu princípio jurídico correlato sob contexto social e normativo nacional, sem descurar das normas internacionais, fazendo-o sob declarada influência da percepção da sociedade brasileira como perpetuadora de um veio histórico escravocrata e uma moral patriarcal, agudizados por uma desigualdade multidimensional, que é fortemente naturalizada tanto por privilegiados quanto por oprimidos. ${ }^{44}$

Quanto às funções cumpridas pelo Princípio da Dignidade da Pessoa Humana na ordem jurídica, aqui são acolhidas três principais e quatro decorrentes, a despeito de Sarmento as apresentar como sete funções autônomas ${ }^{45}$.

A primeira função é a de legitimação do Estado e do Direito, isto é, fundamento da ordem jurídica e política, conforme declarado pelo art. 1.ำ III, da Constituição Federal e afirmado nas diversas declarações e tratados internacionais de direitos humanos, que dá suporte à legitimação moral da máxima segundo a qual Estado e ordem jurídica existem em razão da pessoa humana (e não o contrário).

A segunda é a função de condicionante da hermenêutica jurídica, conferindo legitimação ao uso da dignidade da pessoa humana como guia da interpretação, aplicação e integração do Direito. Desta função decorrem quatro outras afetas ao exercício da aplicação do Direito: diretriz para a ponderação entre interesses colidentes, por meio da técnica da ponderação; critério justificador da limitação de direitos humanos de certa pessoa em razão da dignidade humana de outra pessoa ou em virtude de sua própria dignidade humana;

\footnotetext{
${ }^{44}$ SARMENTO, Daniel. Dignidade da pessoa humana: conteúdo, trajetórias e metodologia. 2. ed. Belo Horizonte: Fórum, 2020, p. 59-68.

${ }^{45}$ SARMENTO, Daniel. Dignidade da pessoa humana: conteúdo, trajetórias e metodologia. 2. ed. Belo Horizonte: Fórum, 2020, p. 77-89. Adotando classificação igual a essa, na substância, embora expressada em um rol mais enxuto, Carvalho Ramos registra exemplos da jurisprudência do STF que corroboram o desempenho das funções assinaladas (RAMOS, André de Carvalho. Curso de Direitos Humanos. 7. ed. São Paulo: Saraiva Educação, 2020, p. 83-85).
} 
Revista Jurídica Trabalho e Desenvolvimento Humano Procuradoria Regional do Trabalho da 15a Região

paradigma para o controle da validade jurídica de atos administrativos, legislativos e jurisdicionais de todo e qualquer agente estatal ("eficácia negativa"), bem assim de atos jurídicos particulares; e critério para a identificação de direitos humanos juridicamente protegidos enunciados no texto constitucional ou de outra norma e que não constam do rol expresso de direitos fundamentais enunciados em trecho específico do Título II da Constituição Federal.

A terceira função é a de fonte de direitos não enumerados ("eficácia positiva") na Constituição Federal ou em normas internacionais vigentes, mas que demandem proteção por dizerem evidente respeito a alguma dimensão da dignidade humana, com isso sanando lacunas ou incompletudes de certa ordem jurídica.

As funções do Princípio da Dignidade da Pessoa Humana permitem afirmar que não se trata de um direito humano autônomo, a despeito do quão confortável isso possa soar do ponto de vista retórico. Em verdade, sob o prisma jurídico-pragmático, afigura-se mais plausível tomar a dignidade, segundo sugere a segunda função enunciada, como fonte subjacente a todos os direitos humanos positivados e não positivados (mas que venham a ser reconhecidos por força de derivação hermenêutica do princípio em questão). ${ }^{46}$ Nesse caso, é possível pensar na figura inusual de um "metadireito". Em sendo assim, não faz sentido classificar a dignidade da pessoa humana como direito humano absoluto, pois, a uma, Ihe falta autonomia e, a duas, compreendido a partir dos direitos humanos específicos nos quais subjaz, estará, tanto quanto esses, suscetível a limitações e restrições legal e jurisprudencialmente estabelecidas. É de se advertir, contudo, que:

(...) o reconhecimento desses direitos não enumerados - "filhotes", por assim dizer, da dignidade humana - , deve ser feito com cautela e critério. Afinal, a afirmação de um direito fundamental gera graves impactos na ordem jurídica e na sociedade, ao ensejar deveres correlatos para o Estado e para particulares. Mais que isso, tal reconhecimento impõe limites para a deliberação das maiorias políticas (...) Vários riscos devem ser evitados nessa atividade, especialmente o decisionismo na "invenção" de novos direitos, a banalização da dignidade e o recurso ao princípio para fundamentar

\footnotetext{
${ }^{46}$ SARMENTO, Daniel. Dignidade da pessoa humana: conteúdo, trajetórias e metodologia. 2. ed. Belo Horizonte: Fórum, 2020, p. 88-89.
} 
Revista Jurídica Trabalho e Desenvolvimento Humano Procuradoria Regional do Trabalho da 15a Região

privilégios não universalizáveis ou promover agendas autoritárias e conservadoras. ${ }^{47}$

Tal advertência remete, então, à definição do âmbito de proteção do Princípio da Dignidade da Pessoa Humana. Por âmbito de proteção de uma norma entende-se o conjunto de situações que se encontram abrangidas pelo direito sob exame. $O$ estudo das funções e a conclusão pela ausência de autonomia do Princípio da Dignidade da Pessoa Humana já permite entrever que não há propriamente um âmbito de proteção a ser precisamente identificado, senão um campo mais vasto, que permita identificar quais dimensões da existência humana concreta estão ao alcance do raio de ação desse princípio jurídico, no cumprimento de suas funções.

Sarmento usa a expressão "componentes" e descreve cinco deles como conformadores do princípio da dignidade da pessoa humana: valor intrínseco da pessoa humana, igualdade, autonomia, mínimo existencial e reconhecimento.

A igualdade, entendida como rejeição de qualquer discriminação ou tratamento social ou cultural hierarquizado, mas que também demanda ações positivas para superação das condutas discriminatórias, já é objeto de disposição normativa específica de direitos humanos, tanto na condição de direito fundamental contemplado em diversas passagens da Constituição Federal (com previsão geral no caput do art. 5.ํ), quanto na de direito humano em incontáveis normas internacionais. Em sendo assim, aos demais componentes incumbe o propósito de iluminar o conteúdo do Princípio da Dignidade da Pessoa Humana, nas situações de desempenho de suas funções.

\subsection{Valor intrínseco da pessoa da pessoa humana}

O valor intrínseco da pessoa da pessoa humana é o componente da dignidade humana que mantém vivo o vínculo com o registro kantiano de matriz ideal universalizante, apresentado em oposição às concepções que admitiam a possibilidade de seres humanos sem

\footnotetext{
${ }^{47}$ SARMENTO, Daniel. Dignidade da pessoa humana: conteúdo, trajetórias e metodologia. 2. ed. Belo Horizonte: Fórum, 2020, p. 89.
} 
Revista Jurídica Trabalho e Desenvolvimento Humano Procuradoria Regional do Trabalho da 15aㅡ Região

dignidade, seja pela posição social, seja em razão de determinados comportamentos éticos (com ou sem vinculação religiosa).

Decorre do valor intrínseco da pessoa humana a máxima da vedação da instrumentalização (objetificação) de qualquer pessoa, resultando na proibição incontornável de quaisquer tratamentos públicos e privados que não observem o ser humano como fim em si mesmo, afastando-se, por conseguinte, as vetustas noções que preceituavam que o indivíduo deve se sacrificar pela sociedade - como fizeram a ideologia organicista ${ }^{48}$ e aqueles que a usaram para justificar regimes políticos autocráticos.

Redução da pessoa à condição análoga à de escravo e outras formas de exploração desmedida da força de trabalho, tráfico humano, assédio moral, tortura decorrente de maus tratos (a exemplo do encarceramento em condições aviltantes) e formas variadas de vilipêndio do corpo alheio - estupro, importunação sexual, assédio sexual, pornografia infantil, divulgação não consentida de fotos e vídeos íntimos de outrem, entre outras consubstanciam, com muita clareza, graves situações de negação do valor intrínseco da pessoa humana e, consequentemente, configuram afronta direta à dignidade humana.

\subsection{Autonomia (Autodeterminação)}

A autonomia ou autodeterminação do ser humano envolve duas dimensões: privada e pública. $^{49}$

\footnotetext{
48 Pertence sobretudo ao campo da teoria política a clássica dicotomia entre as concepções organicistas e individualistas sobre e relação entre governantes e governados. Uma as primeiras formulações organicistas, se não a primeira, é encontrada em "A República" de Platão, com o estabelecimento da compreensão segundo a qual o "todo" é mais importante que suas partes (cidadãos) e, assim, a unidade da pólis é anterior às próprias pessoas e prevalece sobre o interesse dessas. Já sob o contexto contratualista, as diretrizes organicistas mantêmse dentro da figura d'O Leviatã de Hobbes, embora a subjacência dos indivíduos reconhecida pelo modelo hobbesiano ofereça as primeiras pistas para o individualismo que, em oposição ao organicismo, viria a ser desenvolvido pelos contratualistas subsequentes, Locke e Rousseau, a ponto de, não raro, haver uma associação fatalista (não verificada, sempre, na História) entre contratualismo e individualismo, como se pode verificar, por exemplo, das propostas utilitaristas do século XVIII, no contexto do nascimento da economia política. O pensamento individualista inverte a lógica organicista e coloca o Estado (a pólis, o Leviatã, o Soberano etc.) como resultado dos e submissão aos interesses privados dos indivíduos. Em suma, para organicistas, ex parte principis, e para individualistas, ex parte populi (BOBBIO, Norberto. Organicismo e individualismo. Este País, v. 74, n. 9, p. 1-10, maio 1997).

${ }^{49}$ SARMENTO, Daniel. Dignidade da pessoa humana: conteúdo, trajetórias e metodologia. 2. ed. Belo Horizonte: Fórum, 2020, p. 140. A autonomia privada de que se trata não é propriamente aquela pensada por Kant,
} 
Revista Jurídica Trabalho e Desenvolvimento Humano Procuradoria Regional do Trabalho da 15a Região

A autonomia privada é aquela condizente com a liberdade plena do ser humano quanto às escolhas que faz nas várias dimensões de sua existência (afetivas, profissionais, políticas etc.), segundo seus próprios valores, preferências e razões morais. Por certo, na prática, tal autonomia poderá vir a comportar restrições circunstanciais seja por força da referida autonomia da vontade, seja por força de intervenção do Estado, que edita leis restritivas ou julga casos de colisão de direitos humanos, em ambos os casos com a devida justificativa relativa ao respeito, promoção ou proteção de outra dimensão da dignidade humana.

Já a autonomia pública é, ao mesmo tempo, instrumental e constitutiva da dignidade humana, como ensina Amartya Sen, dentro de sua teoria das capacidades. Em favor da importância da preservação a qualquer custo da liberdade política, em contexto democrático, por meio da "preeminência geral dos direitos políticos e civis básicos", apresenta Sen três considerações: (i) importância direta para a vida humana em si, no que diz respeito à capacidade de participação política e social; (ii) papel instrumental de incremento da consideração atribuída a reivindicações políticas, como as de cunho econômico; e (iii) função construtiva na definição de "necessidades" coletivas. ${ }^{50}$ Por óbvio, a democracia em questão deve ser aquela inclusiva e igualitária, já tratada anteriormente.

Nesta esteira, a autonomia pública é instrumental, porque a livre e plena participação na formação da vontade do Estado confere ao ser humano a necessária possibilidade de influir nos rumos da administração pública da vida em sociedade, que, em grande medida, dita as condições materiais oferecidas para que essa mesma pessoa exerça sua autonomia privada afinal, políticas públicas de educação, cultura, saúde, moradia, trabalho e distribuição de renda (para citar apenas algumas), mais do que influenciar, definem obstáculos e possibilidades das escolhas pessoais.

\footnotetext{
tampouco a autonomia da vontade, tão cara aos civilistas. A concepção kantiana admite o exercício da autonomia apenas dentre as escolhas compatíveis com os imperativos morais, excluindo, portanto, a possibilidade de um optar plenamente livre, segundo critérios próprios do indivíduo. Já a autonomia da vontade, enquanto instituto civilista de direito obrigacional, remete à capacidade de se obrigar por força de negócios jurídicos, cuidando-se de noção bem mais limitada e conceitualmente específica de determinado campo do Direito.

50 SEN, Amartya. Desenvolvimento como liberdade. Trad. Laura Teixeira Motta. São Paulo: Companhia das Letras, 2010, p. 195.
} 
Revista Jurídica Trabalho e Desenvolvimento Humano Procuradoria Regional do Trabalho da 15ạ Região

É também constitutiva a autonomia pública porque viabiliza, de um lado, a necessidade básica do ser humano de viver ativamente em sociedade, e, de outro, a participação na discussão pública definidora de valores e preferências coletivas que, adiante, poderão ascender sobre as preferências e oportunidades para efetivação das escolhas pessoais.

A autonomia do ser humano, em ambas as suas dimensões, envolve respeito ("liberdade negativa”) e promoção ("liberdade positiva”). O respeito à autonomia fundamenta o impedimento de intervenções (limitações) injustificadas na liberdade que qualquer pessoa deve ter de fazer escolhas para a própria vida e de participar da formação da vontade do Estado que administra a vida da sociedade em que se insere. Já sua promoção suscita a adoção de medidas orientadas à sua concretude, exigindo sejam providos os meios para seu exercício, meios esses não apenas materiais, mas também culturais atinentes à ampliação das escolhas pessoais privadas e políticas, o que demanda medidas estatais e comportamentos privados orientados à reprovação e superação de tradicionais barreiras culturais à plena autodeterminação de grupos vulneráveis, como é o caso do racismo, do patriarcalismo, da homotransfobia e da xenofobia, entre outras barreiras culturais.

É certo, ainda, que a autodeterminação real (autonomia concreta) também é prerrogativa das pessoas com desenvolvimento cognitivo ainda incompleto ou permanentemente deficiente, que deverão ter sua vontade considerada, na medida do possível de fato, bem como deverão receber do Estado e da sociedade civil ações de promoção dessa autonomia.

Os problemas práticos, com complexas repercussões jurídicas, a respeito sobretudo da autonomia não são poucos e se agudizam em contextos históricos como o atual, permeados por intensa polarização política, com graves desdobramentos no campo moral. Eutanásia, suicídio assistido, prostituição, transfusão de sangue à revelia da crença do paciente, incesto entre adultos, consumo de drogas (lícitas e ilícitas) são apenas alguns dos temas que acaloram debates e atormentam a aplicação do Direito, em especial sob o ponto de vista da intervenção estatal por meio de leis ou da jurisdição.

BELTRAMELLI NETO, Silvio. Conteúdo material e culturalmente inclusivo do Princípio da Dignidade da Pessoa Humana. Revista Jurídica Trabalho e Desenvolvimento Humano, Campinas, v. 4, p. 1-42, 2021. 


\subsection{Mínimo existencial}

O Mínimo Existencial, tal como ordinariamente abordado por doutrina e jurisprudência, se refere às condições materiais de vida conforme os padrões basais de uma existência digna, em determinada conjuntura histórica, ou seja, possibilidade real de plena experimentação dos outros componentes do princípio jurídico da dignidade da pessoa humana. Em sendo assim, o mínimo existencial suscita distintas pretensões positivas ou negativas, muitas já expressamente previstas em outras normas de direitos humanos.

Embora inexista uma disposição legal expressa sobre o mínimo existencial, a promoção de condições materiais de existência aos seres humanos decorre dos objetivos de "erradicar a pobreza e a marginalização e reduzir as desigualdades sociais e regionais" e " promover o bem de todos, sem preconceitos de origem, raça, sexo, cor, idade e quaisquer outras formas de discriminação", consagrados pelo art. 3.ํ, III e IV, da Constituição Federal, na forma de objetivos impostos à República Federativa do Brasil.

Para além dos objetivos, a Carta Constitucional pátria estabelece, por obra dos poderes constituintes originário e derivado, diversos direitos sociais específicos, como os direitos à educação, saúde, alimentação, trabalho, moradia, transporte, lazer, segurança, previdência social, proteção à maternidade e à infância e a assistência aos desamparados (art. 6.o ao 11).

Demais disso, lembre-se, sempre, dos direitos econômicos, sociais, culturais e ambientais (DESCA) garantidos em normas internacionais oponíveis ao Estado brasileiro e que, quando previstos em tratados internacionais devidamente ratificados, complementam o rol constitucional, por força do art. 5.ํ, § 2.ㅇ, da Constituição Federal - v.g. Pacto Internacional sobre Direitos Econômicos, Sociais e Culturais (ONU) e Protocolo Adicional à Convenção Americana sobre Direitos Humanos em Matéria de Direitos Econômicos, Sociais e Culturais - "Protocolo de São Salvador" (OEA).

Não obstante, como visto, é da função do Princípio da Dignidade da Pessoa Humana fundamentar pretensões jurídicas ainda não contempladas em normas jurídicas específicas, desde que atinentes aos componentes de seu conteúdo. Em uma circunstância como essa, por certo, caberá ao Poder Judiciário declarar a procedência de dada pretensão jurídica a certo bem da vida ligado à condição material de existência não respaldada por norma específica, 
Revista Jurídica Trabalho e Desenvolvimento Humano Procuradoria Regional do Trabalho da 15ำ Região

como já fez o STF ao reconhecer, como base no mínimo existencial, o direito ao acesso à água (STF, AgReg em RE 658.171/DF, de 2014) ou, do mesmo modo, o STJ, em relação à rede de tratamento de esgoto (STJ, Resp. 1366331/RS, de 2014).

Seja como for, a implementação de direitos atinentes ao mínimo existencial comumente enseja pródiga controvérsia sobre dois pontos sensíveis, um decorrente do outro: (i) sua implicação orçamentária, ainda que se trate de discussão relativa a determinado indivíduo, sempre travada com argumentos que remetem aos impactos econômicos da replicação da medida para o restante da população deficitária na experimentação do direito social em debate; (ii) possível usurpação pelo Poder Judiciário de sua competência, com afronta à tripartição de Poderes, ao intervir na gestão do erário público, entregue ao Poder Executivo.

A limitação econômica para a implementação em caráter geral de direitos correlatos ao mínimo existencial compõe o argumento conhecido como "reserva do possível", segundo - qual direitos econômicos sociais e culturais devem ser satisfeitos gradual e progressivamente, na medida das possibilidades orçamentárias. No STF, decisão monocrática de 2004 do então Ministro Celso de Mello para a ADPF 45/DF-MC é considerada leading case acerca do tema. A ação versava sobre a validade de veto presidencial à disposição da Lei de Diretrizes Orçamentárias anual de 2004, que assegurava um patamar de recursos financeiros para investimentos na área da saúde. A referida decisão monocrática extinguiu-a por perda de objeto decorrente do envio de proposta substitutiva daquela Lei ao Congresso Nacional, todavia, não deixou de se referir a ambos os pontos sensíveis do debate, ao explicitar que a atuação do Poder Judiciário em relação às ações estatais de implementação de direitos correlatos ao mínimo existencial deve ser excepcional e pautada em omissão ou ação inadequada predatória dos demais Poderes e que o argumento da reserva do possível não pode ser acatado a priori, devendo estar calcado em demonstração inequívoca (fática) de sua procedência, à luz do caso concreto sob análise judicial.

Desde então, pode-se se dizer que o STF abraçou a noção de mínimo existencial, tendo desse se valido para fundamentar o deferimento de pretensões de diversas naturezas. ${ }^{51}$

\footnotetext{
51 Exemplificativamente: RE 592.581/RS, de 2015, ADPF 347/DF-MC, de 2015, RE 580.252/MS, de 2015 e RE 482.211/SC, de 2010 .
}

BeltRAMELLI NETO, Silvio. Conteúdo material e culturalmente inclusivo do Princípio da Dignidade da Pessoa Humana. Revista Jurídica Trabalho e Desenvolvimento Humano, Campinas, v. 4, p. 1-42, 2021. 
Revista Jurídica Trabalho e Desenvolvimento Humano Procuradoria Regional do Trabalho da 15a Região

A definição das condições materiais e pretensões albergadas pelo mínimo existencial é outro assunto que provoca candentes discussões. Na linha de uma identificação a priori dessas condições materiais e observando o cabimento do argumento da reserva do possível, contanto que faticamente comprovado, o Comitê de Direitos Econômicos, Sociais e Culturais da ONU, responsável por interpretar e monitorar o cumprimento pelos Estados Partes do Pacto de Direitos Econômicos, Sociais e Culturais de 1966, editou, em 1990, o ComentárioGeral n. 3, cujo item 10 preceitua que:

(..) um núcleo mínimo de obrigações para assegurar a satisfação de níveis mínimos essenciais de cada um dos direitos é incumbência de cada Estado Parte. Assim, por exemplo, um Estado Parte em que qualquer número significativo de indivíduos é privado de gêneros alimentícios essenciais, de cuidados essenciais de saúde, de abrigo e habitação básicos ou das mais básicas formas de educação está, à primeira vista, falhando para desincumbir-se de suas obrigações em relação ao Pacto. Se o Pacto fosse interpretado no sentido de não estabelecer tal núcleo mínimo de obrigações, seria largamente privado de sua razão de ser. Além disso, deve ser observado que, em relação a qualquer avaliação no sentido de verificar se o Estado se desincumbiu desse núcleo mínimo de obrigações, deve-se também levar em conta as restrições de recursos disponíveis no país considerado. $\mathrm{O}$ artigo 20 (1) obriga cada Estado Parte a tomar as medidas necessárias "até o máximo de seus recursos disponíveis". Para que um Estado-Parte atribua seu fracasso em cumprir seu núcleo mínimo de obrigações à falta de recursos disponíveis, ele deve demonstrar que todo esforço foi feito para usar todos os recursos que estão à disposição num empenho para satisfazer, como matéria de prioridade, essas obrigações mínimas. $^{52}$

Entretanto, não são poucos os autores que se recusam a admitir a existência de um rol exauriente de pretensões e situações conformadoras do mínimo existencial, o que se mostra mais adequado, em termos de preservação de uma efetividade mais ampla do que se pretende com a afirmação de sua faceta jurídica, portanto, obrigacional. ${ }^{53}$

\footnotetext{
52 Tradução livre de: UNITED NATIONS. COMMITTEE ON ECONOMIC, SOCIAL AND CULTURAL RIGHTS. General comment No. 3: The nature of States parties' obligations (art. 2, para. 1, of the Covenant). Genebra, 1990. Disponível

em: https://tbinternet.ohchr.org/Treaties/CESCR/Shared\%20Documents/1 Global/INT CESCR GEC 4758 E.doc. Acesso em: 30 out. 2020.

${ }^{53}$ SARMENTO, Daniel. Dignidade da pessoa humana: conteúdo, trajetórias e metodologia. 2. ed. Belo Horizonte: Fórum, 2020, p. 219.
} 
Revista Jurídica Trabalho e Desenvolvimento Humano Procuradoria Regional do Trabalho da 15a Região

A relação entre mínimo existencial e democracia é direta e de implicação. É que a implementação de adequadas condições materiais de existência depende, no geral, de políticas públicas estatais formuladas e, em larga medida, executadas por governantes eleitos. Se por um lado, pessoas com mais acesso à saúde, educação e cultura tendem a melhor exercitar seu papel dentro da democracia indireta, com isso elevando o grau de exigência junto a candidatos e representantes eleitos, por outro, é fundamental a garantia da participação democrática e deliberativa da sociedade civil - notadamente dos econômica e culturalmente vulneráveis - nos processos de formulação e acompanhamento da execução das políticas públicas que visam, justamente, incrementar as condições materiais de vida das pessoas. ${ }^{54}$

Trata-se de um círculo virtuoso: a participação da sociedade civil na definição e monitoramento da execução de medidas de promoção e salvaguarda do mínimo existencial acarreta aperfeiçoamento da participação política de indivíduos, a resultar, por conseguinte, em políticas públicas mais adequadas à elevação das condições materiais de existência humana, em sentido coletivo.

Ainda dentro das reflexões sobre o conteúdo e o alcance do mínimo existencial, interessante distinção tem sido verificada na Alemanha entre "mínimo existencial fisiológico" e "mínimo existencial sociocultural". O primeiro denota as condições materiais mínimas de uma vida digna, enquanto o segundo realça a promoção da inserção igualitária das pessoas na vida em sociedade, instigando, para além do acesso a bens materiais de existência adequada, a promoção desse acesso de modo não discriminatório, segundo qualquer tipo de critério distintivo e não apenas o econômico ${ }^{55}$. $\mathrm{O}$ aspecto cultural da igualdade material conduz ao exame do reconhecimento, último componente do princípio jurídico da dignidade da pessoa humana.

\footnotetext{
${ }^{54}$ Acerca do imperativo da participação democrática deliberativa (com poder de voz e voto) da sociedade civil na formulação e acompanhamento de execução de políticas púbicas, cf. ALVES, Felipe Dalenogare; FRIEDRICH, Denise Bittencourt. O necessário empoderamento do cidadão à efetivação das políticas públicas no Brasil: a contribuição do capital social à efetiva participação nos instrumentos democrático-participativo-deliberativos. Revista de Direito da Cidade, v. 9, n. 2, p. 725-753, 26 abr. 2017.

55 SARLET, Ingo W.; FIGUEIREDO, Mariana Filchtiner. Reserva do possível, mínimo existencial e direito à saúde. Revista Brasileira de Direitos Fundamentais \& Justiça, v. 1, n. 1, p. 171-213, 2007, p. 181.
} 
Revista Jurídica Trabalho e Desenvolvimento Humano Procuradoria Regional do Trabalho da 15a Região

\subsection{Reconhecimento}

O reconhecimento "não significa simplesmente a identificação cognitiva de uma pessoa por outra, mas sim, tendo esse ato como premissa, a atribuição de um valor positivo à pessoa reconhecida, algo próximo do que entendemos por respeito". ${ }^{56}$

O tema entra para o debate filosófico pelas mãos de Hegel, o qual, na obra "Fenomenologia do Espírito", mas especificamente na seção "Senhorio e Escravo", o aponta como algo a ser conquistado, diferentemente de Kant, para quem o reconhecimento da importância de outrem decorre da ideia de pessoa como fim em si mesma e de sua pressuposta autonomia, ao feitio de um atributo pré-concebido.

Hegel parte do pressuposto segundo o qual a individualidade de cada consciência no mundo não reconhece qualquer autonomia de outras consciências, bem por isso tendendo a impor suas convicções e projetos como condição de reconhecimento dos demais. Todavia, para Hegel, o reconhecimento como resultante da imposição de uma convicção moral e prática, embora comportamento ínsito ao estado de natureza hobbesiano, não é, de fato, reconhecimento, senão apenas subjugação. Em sendo assim, só haverá reconhecimento em circunstâncias nas quais quem reconhece o valor do outro também tem seu valor reconhecido por esse último. Em suma, a reciprocidade é condição para o reconhecimento e sua obtenção jamais pode ser pressuposta, por tratar-se de uma situação obtida apenas a partir de processos concretos de conquista, nos âmbitos da sociedade, do mercado e do Estado. Tal processo é denominado por Hegel "luta pelo reconhecimento" 57.

A proposta hegeliana da luta por reconhecimento somente viria a ser resgatada, na contemporaneidade, pelo filósofo canadense Charles Taylor, que chama a atenção para a grave consequência do não reconhecimento nos campos da família, da sociedade civil e do Estado, qual seja, a redução da capacidade da pessoa não reconhecida de construir autoestima e, por conseguinte, de perceber-se em sua individualidade, assim como de ser

\footnotetext{
56 ASSY, Bethânia; FERES JÚNIOR, João. Reconhecimento (verbete). In BARRETTO, Vicente de Paulo (Org.). Dicionário de Filosofia do Direito. São Leopoldo: Editora Unisinos, 2006, p. 705.

57 ASSY, Bethânia; FERES JÚNIOR, João. Reconhecimento (verbete). In BARRETTO, Vicente de Paulo (Org.). Dicionário de Filosofia do Direito. São Leopoldo: Editora Unisinos, 2006, p. 706-707.
} 
Revista Jurídica Trabalho e Desenvolvimento Humano Procuradoria Regional do Trabalho da 15ำ Região

percebida como sujeito de direitos. ${ }^{58} \mathrm{~A}$ recuperação do tema por Taylor suscitou a disseminação dos debates e reflexões sobre reconhecimento, em especial na seara da teoria crítica contemporânea.

De enorme relevo é a teoria do reconhecimento do filósofo alemão Axel Honneth, formulada, de modo interdisciplinar, a partir da associação de conceitos hegelianos com contribuições da psicologia social do filósofo norte-americano George Herbert Mead, pretendendo-se dar à proposta de Hegel uma "inflexão materialista". ${ }^{59}$ Reeditando, à sua maneira, a ideia hegeliana de amor, direito e solidariedade como etapas do reconhecimento, Honneth identifica três formas progressivas ou modos de reconhecimento: dedicação emotiva, respeito cognoscitivo e estima social. O reconhecimento pela dedicação emotiva, de natureza carencial/afetiva, revela-se nas relações primárias de amor e amizade, que ensejam autoconfiança. O reconhecimento pelo respeito cognoscitivo experimenta-se pela atribuição de direitos, que propiciam autorrespeito. Já o reconhecimento pela estima social dá-se pela consideração recíproca ("estima simétrica") entre indivíduos autônomos, dentro de um sistema de valores em que as "capacidades e propriedades" do outro sejam significativas para a praxe comum, consubstanciando um ambiente de solidariedade, que dá azo à autoestima.

Sob uma perspectiva negativa individual, a ausência de dedicação emotiva agride a integridade física e emocional, a negação de direitos provoca exclusão e o déficit de estima social degrada e ofende a honra. É exatamente essa conjuntura negativa que move, segundo Honneth, a luta por reconhecimento. ${ }^{60}$

A necessidade de se pensar e agir para o reconhecimento desde uma perspectiva efetivamente material - ou seja, que parta da concretude dos fatores reais de desigualdade que influem nos déficits de reconhecimento - levou a filósofa estadunidense Nancy Fraser a criticar o que classifica como excessiva psicologização da teoria de Honneth. ${ }^{61}$

\footnotetext{
58 ASSY, Bethânia; FERES JÚNIOR, João. Reconhecimento (verbete). In BARRETTO, Vicente de Paulo (Org.). Dicionário de Filosofia do Direito. São Leopoldo: Editora Unisinos, 2006, p. 706.

59 HONNETH, Axel. Luta por reconhecimento: a gramática moral dos conflitos sociais. Trad. Luiz Sérgio Repa. São Paulo: Ed. 34, 2011, p. 23-26 e 155.

${ }^{60}$ HONNETH, Axel. Luta por reconhecimento: a gramática moral dos conflitos sociais. Trad. Luiz Sérgio Repa. São Paulo: Ed. 34, 2011, p. 155-211.

61 "Lutas pelo reconhecimento ocorrem num mundo de exacerbada desigualdade material - desigualdades de renda e propriedade; de acesso a trabalho remunerado, educação, saúde e lazer; e também, mais cruamente, de ingestão calórica e exposição à contaminação ambiental; portanto, de expectativa de vida e de taxas de
} 
Revista Jurídica Trabalho e Desenvolvimento Humano Procuradoria Regional do Trabalho da 15a Região

Em sua teoria da justiça, que congrega a análise distintiva, mas interativa, entre injustiças econômicas e culturais, sustenta Fraser que a luta por reconhecimento (eminentemente cultural) não pode substituir a luta por redistribuição (em face da desigualdade socioeconômica), tratando-se de reivindicações que devem seguir juntas. Segundo tal proposta, a luta por redistribuição abrange "não só a transferência de rendimentos, mas também a reorganização da divisão do trabalho, a transformação da estrutura da posse da propriedade e a democratização dos processos através dos quais se tomam decisões relativas ao investimento". Já a luta por reconhecimento contempla, por um lado, "a revalorização das identidades desrespeitadas e os produtos culturais de grupos discriminados" e os "esforços de reconhecimento e valorização da diversidade", e, por outro, "os esforços de transformação da ordem simbólica e de desconstrução dos termos que estão subjacentes às diferenciações de estatuto existentes, de forma a mudar a identidade social de todos". 62

Cuidam-se, portanto, de lutas com pautas próprias, mas que podem se retroinfluenciar para o bem ou para o mal ${ }^{63}$, sendo desejável que a primeira situação seja buscada nas estratégias reivindicatórias, contudo, sua possibilidade torna-se concretamente viável apenas em contexto democrático que garanta, nos dizeres de Fraser, o "princípio normativo da paridade de participação", a saber:

O que é preciso é um único princípio normativo que inclua as reivindicações justificadas quer de redistribuição, quer de reconhecimento, sem reduzir umas às outras. Com este propósito, proponho o princípio de paridade de participação, segundo o qual a justiça requer arranjos sociais que permitam a todos os membros (adultos) da sociedade interagir entre si como pares. São necessárias pelo menos duas condições para que a paridade participativa seja possível. Primeiro, deve haver uma distribuição de recursos materiais que garanta a independência e "voz" dos participantes. Esta condição impede a existência de formas e níveis de dependência e desigualdade econômicas que constituem obstáculos à paridade de participação. Estão excluídos, portanto, arranjos sociais que institucionalizam a privação, a exploração e as flagrantes disparidades de

morbidade e mortalidade" (FRASER, Nancy. Da redistribuição ao reconhecimento? Dilemas da justiça numa era "pós-socialista". Trad. Júlia Assis Simões. Cadernos de Campo, v. 15, n. 14-15, p. 231-239, 2006, p. 231).

62 FRASER, Nancy. A justiça social na globalização: redistribuição, reconhecimento e participação. Trad. Teresa Tavares. Revista Crítica de Ciências Sociais, n. 63, p. 07-20, 1 out. 2002, p. 11-12.

63 FRASER, Nancy. A justiça social na globalização: redistribuição, reconhecimento e participação. Trad. Teresa Tavares. Revista Crítica de Ciências Sociais, n. 63, p. 07-20, 1 out. 2002, p. 237-239. 
Revista Jurídica Trabalho e Desenvolvimento Humano Procuradoria Regional do Trabalho da 15a Região

riqueza, rendimento e tempo de lazer que negam a alguns os meios e as oportunidades de interagir com outros como pares. Em contraponto, a segunda condição para a paridade participativa requer que os padrões institucionalizados de valor cultural exprimam igual respeito por todos os participantes e garantam iguais oportunidades para alcançar a consideração social. Esta condição exclui padrões institucionalizados de valor que sistematicamente depreciam algumas categorias de pessoas e as características a elas associadas. Portanto, excluem-se padrões institucionalizados de valor que negam a alguns o estatuto de parceiros plenos nas interacções - quer ao imputar-lhes a carga de uma "diferença" excessiva, quer ao não reconhecer a sua particularidade. ${ }^{64}$

Aliás, a participação democrática em espaços deliberativos como instrumento essencial ao reconhecimento ganha centralidade no pensamento da cientista política e filósofa turca Seyla Benhabib - influenciado por Hanna Arendt e Jürgen Habermas -, cuja obra enfatiza a alta diversidade de demandas no campo do reconhecimento, uma vez que identidades e práticas culturais não são estanques, mas fluidas, interpenetrando-se, sobretudo após as interações favorecidas pela globalização. Deste modo, o reconhecimento não se atém à valorização desse ou daquele grupo cultural, senão deve, igualmente, permitir suas intersecções, de forma a que a pessoa possa, inclusive, recusar-se a seguir o padrão cultural prestigiado, por exemplo, pelo Estado que rege a sociedade em que está inserida.

Para Benhabib, é possível e desejável que se conjuguem direitos humanos estabelecidos pela comunidade internacional, com sentido de universalidade, e reivindicações e direitos de pessoas que lutam por reconhecimento, inclusive de identidades e práticas culturais localizadas e delimitadas, contanto que exista a garantia de representatividade aos grupos culturalmente vulneráveis em todos os níveis de espaços institucionais de deliberação, desde o patamar local até o global ${ }^{65}$.

\footnotetext{
${ }^{64}$ FRASER, Nancy. A justiça social na globalização: redistribuição, reconhecimento e participação. Trad. Teresa Tavares. Revista Crítica de Ciências Sociais, n. 63, p. 07-20, 1 out. 2002, p. 13. Salienta-se, contudo, que a proposta de paridade de participação deve respeitar a natureza das reivindicações, dos espaços e dos agentes envolvidos, não havendo uma fórmula universal a ser observada, mas sim, nas palavras da pensadora, "uma multiplicidade de enquadramentos" relativos a pautas e interações (FRASER, Nancy. A justiça social na globalização: redistribuição, reconhecimento e participação. Trad. Teresa Tavares. Revista Crítica de Ciências Sociais, n. 63, p. 07-20, 1 out. 2002, p. 18-19).

${ }^{65}$ BENHABIB, Seyla. The claims of culture: equality and diversity in the Global Era. Princeton: Princeton University Press, 2002, p. 178-186; BENHABIB, Seyla. Another Universalism: On the Unity and Diversity of Human Rights. Proceedings and Addresses of the American Philosophical Association, v. 81, n. 2, p. 7-32, 2007.
} 
Revista Jurídica Trabalho e Desenvolvimento Humano Procuradoria Regional do Trabalho da 15aㅡ Região

Diante desse cenário teórico, o reconhecimento se revela o componente do Princípio da Dignidade da Pessoa Humana que fundamenta o argumento em favor da existência, na esfera jurídica, de um direito geral de todo ser humano e de um correlato dever do Estado e da sociedade civil de reconhecimento, respeito e valorização à identidade subjetiva, com consequente proteção de estigmatizados por conta de diferenças identitárias advindas do que possa ser compreendido como padrões de existência socialmente predominantes e, por isso, pretensamente recomendáveis.

Esse direito impõe aos obrigados públicos e privados a abstenção de intervenções em relação à identidade de quem quer que seja e a promoção de ações inclusivas dessas pessoas, considerando os déficits em relação aos demais componentes do Princípio da Dignidade da Pessoa Humana, experimentados justamente pela opressão cultural impingida aos vulneráveis em questão, dentre os quais mulheres, negras e negros, indígenas, pessoas que integram a comunidade LGBTQIA+, migrantes, adeptos de distintas religiões ou mesmo de nenhuma delas.

A diversidade cultural, compreendida em sentido lato, encontra-se robustamente protegida pelas normas internacionais de direitos humanos, quer por cláusulas gerais de afirmação da igualdade no gozo de direitos, quer por disposições ou mesmo documentos normativos específicos. ${ }^{66}$

Com vistas a dissipar qualquer dúvida sobre o alcance das regras gerais de igualdade, na esteira da aprovação pela Assembleia Geral da ONU da Resolução n.o 2435, de 2008, intitulada "Direitos Humanos, Orientação Sexual e Identidade de Gênero" - pela qual os Estados Membros manifestaram preocupação com os atos de violência e violações aos direitos humanos correlatas à condição das pessoas que compõem o grupo LGBTQIA+ -, o Comitê que monitora o cumprimento do Pacto Internacional sobre Direitos Econômicos, Sociais e Culturais editou, em 2009, o Comentário Geral n. 20, o qual fixa a interpretação

\footnotetext{
${ }^{66}$ Exemplo de norma geral de proteção da igualdade no contexto do reconhecimento é o artigo 2. da Declaração Universal dos Direitos Humanos: "Toda pessoa tem capacidade para gozar os direitos e as liberdades estabelecidos nesta Declaração, sem distinção de qualquer espécie, seja de raça, cor, sexo, língua, religião, opinião política ou de outra natureza, origem nacional ou social, riqueza, nascimento, ou qualquer outra condição". A expressão "outra condição" denota abertura do rol de situações de discriminação reprovadas pelos direitos humanos, admitindo, consequentemente, ampliação decorrente da própria dinâmica social.
} 
Revista Jurídica Trabalho e Desenvolvimento Humano Procuradoria Regional do Trabalho da 15a Região

segundo a qual é aberto o horizonte subjetivo de proteção da cláusula geral de proibição de discriminação, abarcando, segundo rol não exaustivo examinado pelo Comitê, deficiência, idade, nacionalidade, estado civil e familiar, orientação sexual e identidade de gênero, estado de saúde, local de residência e situação econômica e social de pobreza ou desabrigo. ${ }^{67}$

Já tratados internacionais específicos sobre grupos afetados por déficit de reconhecimento há nos diferentes sistemas de proteção dos direitos humanos, cabendo citar, ilustrativamente, alguns aprovados na seara dos sistemas aos quais o Estado brasileiro rende contas.

A ONU tem vigentes a Convenção sobre a Eliminação de Todas as Formas de Discriminação Racial, a Convenção sobre a Eliminação de Todas as Formas de Discriminação contra a Mulher, a Convenção sobre os Direitos das Pessoas com Deficiência, a Convenção Internacional sobre a Proteção dos Direitos de Todos os Trabalhadores Migrantes e suas Famílias (única das citadas ainda não ratificada pelo Brasil) e a Declaração sobre os Direitos das Pessoas Pertencentes a Minorias Nacionais ou Étnicas, Religiosas e Linguísticas.

Já a OEA conta com a Convenção Interamericana sobre Concessão dos Direitos Políticos à Mulher, a Convenção Interamericana para Prevenir, Punir e Erradicar a Violência contra a Mulher ("Convenção de Belém do Pará"), a Convenção Interamericana contra o Racismo, a Discriminação Racial e Formas Conexas de Intolerância, a Convenção Interamericana Contra Toda Forma de Discriminação e Intolerância e a Convenção Interamericana para a Eliminação de todas as Formas de Discriminação Contra as Pessoas com Deficiência.

Especificamente no campo da identidade de gênero e sexualidade, no ano de 2006, um grupo culturalmente diverso de vinte e nove eminentes especialistas em direitos humanos, provenientes de vinte e cinco países, após reunirem-se na Universidade Gadjah Mada, em Yogyakarta, Indonésia, editaram, tornaram público e encaminharam ao Conselho de Direitos Humanos da ONU documento intitulado "Princípios sobre a Aplicação da

\footnotetext{
67 UNITED NATIONS. COMMITTEE ON ECONOMIC, SOCIAL AND CULTURAL RIGHTS. General comment No. 20: Non-discrimination in economic, social and cultural rights (art. 2, para. 2, of the International Covenant on Economic, Social and Cultural Rights). Geneve, 2009. Disponível em: https://tbinternet.ohchr.org/ layouts/15/treatybodyexternal/Download.aspx?symbolno=E\%2fC.12\%2fGC $\% 2 \mathrm{f2}$ 0\&Lang=en. Acesso em: 30 out. 2020.
}

BELTRAMELLI NETO, Silvio. Conteúdo material e culturalmente inclusivo do Princípio da Dignidade da Pessoa Humana. Revista Jurídica Trabalho e Desenvolvimento Humano, Campinas, v. 4, p. 1-42, 2021. 
Revista Jurídica Trabalho e Desenvolvimento Humano Procuradoria Regional do Trabalho da 15a Região

Legislação Internacional de Direitos Humanos em Relação à Orientação Sexual e Identidade de Gênero", que veio a ser expandido em 2017, para considerar aspectos de interseccionalidade e incluir mais formas de expressão de gênero e características sexuais, além de 10 (dez) novos princípios. Mais conhecido como Princípios de Yogyakarta, o referido documento não consubstancia norma jurídica vinculante, mas trata exatamente do alcance das normas gerais e específicas internacionais de direitos humanos vigentes.

Tendo sua relevância reconhecida pela comunidade internacional em sentido amplo (ONU, ONGs e academia), os Princípios de Yogyakarta reconhecem que: "há um valor significativo em articular de forma sistemática a legislação internacional de direitos humanos como sendo aplicável à vida e à experiência de pessoas de orientações sexuais e identidades de gênero diversas". O documento salienta deveres dos Estados em relação ao respeito, promoção e proteção de dezenas de direitos humanos em face de pessoas discriminadas em razão de diversidade de orientação sexual e identidade de gênero. ${ }^{68}$

No plano nacional, inexiste, na Constituição Federal brasileira, um dispositivo que declare, expressamente, a existência de um direito fundamental ao reconhecimento. Todavia, para além de um direito geral albergado pelo Princípio da Dignidade da Pessoa Humana, o texto constitucional pátrio conta com previsões gerais e específicas sobre respeito, promoção e proteção da igualdade, no campo da luta pelo reconhecimento, a saber: erradicação das desigualdades sociais e promoção do bem de todos, sem discriminação de qualquer natureza (art. 3.ํ, III e IV); reprovação, inclusive criminal, do racismo (arts. 3.ํ, IV; 4.ํ, VIII; 5.ํ, XLII), dever de punição legal à discriminação atentatória dos direitos e liberdades fundamentais (art. 5.ํ, XLI), proteção à cultura indígena e afro-brasileira (art. $215, \S 1$. ) e assistência e ações inclusivas dirigidas a pessoas com deficiência (arts. 7.․․ XXXI; 23, II; 24, XIV; 37, VIII, 40, § 4. ;

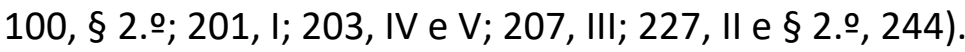

Diante deste cenário teórico e normativo, é possível afirmar que a luta por reconhecimento é uma realidade no campo jurídico, tendo obtido relevantes avanços nos

68 COMISSÃO INTERNACIONAL DE JURISTAS; SERVIÇO INTERNACIONAL DE DIREITOS HUMANOS. Princípios de Yogyakarta: princípios sobre a aplicação da legislação internacional de direitos humanos em relação à orientação sexual e identidade de gênero. Indonésia: Universidade Gadjah Mada, 2006. Disponível em: http://www.dhnet.org.br/direitos/sos/gays/principios de yogyakarta.pdf. Acesso em: 19 nov. 2020. 
Revista Jurídica Trabalho e Desenvolvimento Humano Procuradoria Regional do Trabalho da 15ำ Região

espaços regulatórios nacional e internacional, conquanto ainda haja um longo caminho para que os mandamentos legais se verifiquem, de modo prevalente, nas relações sociais.

\section{CONSIDERAÇÕES FINAIS}

A complexidade da determinação do alcance do Princípio da Dignidade da Pessoa Humana é diretamente proporcional à amplitude de seu conteúdo e à diversidade de suas funções.

A abordagem mais acurada das transformações históricas do sentido da dignidade humana revela que, embora comumente tratada como atributo inerente ao ser humano, à feição kantiana, sua verificação dá-se no contexto das relações sociais (histórico-políticoculturais) em que inserida a pessoa, sofrendo influências e, por isso, comportando individualização. Dito de outro modo, todo ser humano tem dignidade, mas cada qual a ostenta com características e sob condições pessoais e materiais próprias, particulares.

Um olhar para os componentes do conteúdo do Princípio da Dignidade da Pessoa Humana corrobora sua dualidade universal/particular, na medida em que o valor intrínseco e sua autonomia dizem respeito a atributos a serem salvaguardados a todos, indistintamente e na mesma intensidade. Por outro lado, o mínimo existencial e o reconhecimento se estabelecem como componentes do princípio em questão exatamente porque particularidades da experiência humana, ligadas à desigualdade material e à identidade, se afirmam como condenáveis motivos de negação dos dois primeiros componentes. Compreende-se, bem por isso, que os componentes do Princípio da Dignidade da Pessoa Humana são absolutamente interrelacionados, influenciando-se mutuamente.

A dignidade humana é, portanto, multifacetada porque emerge das distintas esferas da existência humana, dentro das quais manifestam-se situações fáticas atinentes a cada qual dos quatro componentes do Princípio da Dignidade da Pessoa Humana. Por ostentar um conteúdo multifacetado associado a funções também complexas - legitimação do Estado e do Direito, condicionante da hermenêutica jurídica e fonte de direitos não enumerados - , o Princípio da Dignidade da Pessoa Humana oferece enormes desafios à sua aplicação aos casos concretos.

BELTRAMELLI NETO, Silvio. Conteúdo material e culturalmente inclusivo do Princípio da Dignidade da Pessoa Humana. Revista Jurídica Trabalho e Desenvolvimento Humano, Campinas, v. 4, p. 1-42, 2021. 
Revista Jurídica Trabalho e Desenvolvimento Humano Procuradoria Regional do Trabalho da 15a Região

A própria natureza do Princípio da Dignidade da Pessoa Humana enquanto direito humano específico é objeto de intensa controvérsia doutrinária. É certo que os textos dos tratados internacionais de direitos e da própria Constituição Federal brasileira não enunciam a dignidade da pessoa humana como direito fundamental específico.

Pensa-se que o mais adequado tratamento à questão advém da própria compreensão da qualidade de metadireito, combinada com as funções do Princípio da Dignidade da Pessoa Humana que dizem respeito ao condicionamento da interpretação/aplicação das normas vigentes e à fundamentação para novos direitos humanos específicos ainda não explicitados em lei, de modo extraordinário - apenas e tão somente nos casos concretos em que sua admissão seja imperativo de salvaguarda de quaisquer daqueles componentes que conformam o princípio de que se cuida.

Razoavelmente assentado em termos doutrinários e jurisprudenciais é o uso do Princípio da Dignidade da Pessoa Humana como valor moral e jurídico fundante de todos os direitos humanos específicos positivados, de forma expressa, em normas escritas nacionais e internacionais. Nessa hipótese, a aplicação de determinado direito humano tem no Princípio da Dignidade da Pessoa Humana uma metanorma (a que corresponde um metadireito) subjacente, cuja invocação se justifica como parâmetro condutor do exercício hermenêutico de extração de sentido daquela norma específica de direito humano, orientada à solução do caso concreto. Em casos de colisão de normas de direitos humanos, o Princípio da Dignidade da Pessoa Humana também pode ser suscitado para o direcionamento da análise demandada pelas técnicas de ponderação e proporcionalidade (examinadas em seus detalhes em capítulo posterior).

A questão é mais tormentosa, porém, quando se cuida de decisão que aplica o Princípio da Dignidade da Pessoa Humana de forma autônoma, pois envolve, mais imediatamente, a celeuma sobre os contornos da atividade criativa de juízes e juízas e, em última instância, o debate sobre os limites da competência do Poder Judiciário frente ao devido equilíbrio do sistema de freios e contrapesos, que deve permear a relação entre os Três Poderes.

O Princípio da Dignidade da Pessoa Humana não se presta a ser utilizado como instrumento discricionário bloqueador a priori da aplicação de qualquer norma jurídica 
Revista Jurídica Trabalho e Desenvolvimento Humano Procuradoria Regional do Trabalho da 15a Região

vigente. Outrossim, não convém "inflacionar" a aplicação do Princípio da Dignidade da Pessoa Humana, banalizando-o. Bem por isso, reafirma-se a necessidade de critérios fundamentados de aplicação, que se mostrem claros e precisos, a serem estabelecidos pelas autoridades jurisdicionais, pois, dessa maneira, estipular-se-á uma referência que, a um só tempo, servirá como diretriz e moldura hermenêuticas, dotadas de possibilidades e limites vislumbráveis, assim como espelho para a discussão pública das razões de decidir pelas partes e pela sociedade.

O que tais critérios jamais podem olvidar, todavia, é que o Princípio da Pessoa Humana exige seja dada máxima proteção aos direitos à igualdade material e ao reconhecimento, o que reclama, necessariamente, a preservação de espaços institucionais deliberativos que assegurem representação plural de todos os grupos econômica e culturalmente vulneráveis.

\section{REFERÊNCIAS}

AIETA, Vânia S. Democracia. In: BARRETO, Vicente de P. (Coord.). Dicionário de filosofia do direito. São Leopoldo/Rio de Janeiro: Editora Unisinos; Livraria Editora Renovar, 2009.

ALVES, Felipe Dalenogare; FRIEDRICH, Denise Bittencourt. O necessário empoderamento do cidadão à efetivação das políticas públicas no Brasil: a contribuição do capital social à efetiva participação nos instrumentos democrático-participativo-deliberativos. Revista de Direito da Cidade, v. 9, n. 2, p. 725-753, 26 abr. 2017.

ASSY, Bethânia; FERES JÚNIOR, João. Reconhecimento (verbete). In BARRETTO, Vicente de Paulo (Org.). Dicionário de Filosofia do Direito. São Leopoldo: Editora Unisinos, 2006.

BARCELLOS, Ana Paula de. Normatividade dos princípios e o princípio da dignidade da pessoa humana na Constituição de 1988. Revista de direito administrativo, v. 221, p. 159$188,2000$.

BELTRAMELLI NETO, Silvio. Exclusão social, regulação do trabalho e crise do sindicalismo nas perspectivas crítica e utópica de Boaventura de Sousa Santos. Revista Direito e Práxis, v. 11, n. 3, p. 1815-1844, set. 2020. Disponível em:

http://www.scielo.br/scielo.php?script=sci abstract\&pid=S217989662020000301815\&lng=en\&nrm=iso\&tlng=pt. Acesso em: 09 fev. 2021.

BELTRAMELLI NETO, Silvio; BONAMIM, Isadora Rezende; VOLTANI, Julia de Carvalho. Trabalho Decente segundo a OIT: uma concepção democrática? Análise crítica à luz da teoria 
Revista Jurídica Trabalho e Desenvolvimento Humano Procuradoria Regional do Trabalho da 15a Região

do contrato social. Revista Eletrônica do Curso de Direito da UFSM, v. 14, n. 1, p. 1-36, 6 maio 2019. Disponível em: https://periodicos.ufsm.br/revistadireito/article/view/33853. Acesso em: 09 fev. 2021.

BENHABIB, Seyla. Another Universalism: On the Unity and Diversity of Human Rights.

Proceedings and Addresses of the American Philosophical Association, v. 81, n. 2, p. 7-32, 2007.

BENHABIB, Seyla. The claims of culture: equality and diversity in the Global Era. Princeton: Princeton University Press, 2002.

BITTAR, Eduardo C. B. Ética, Cidadania e Constituição: o direito à dignidade e à condição humana. Revista Brasileira de Direito Constitucional, v. 8, n. 1, p. 125-155-155, 31 dez. 2006.

BOBBIO, Norberto. Organicismo e individualismo. Este País, v. 74, n. 9, p. 1-10, maio 1997.

CAMPOS, André de. et. al. Atlas da exclusão social no Brasil, volume 2: dinâmica e manifestação territorial. São Paulo: Cortez: 2003.

COMISSÃO INTERNACIONAL DE JURISTAS; SERVIÇO INTERNACIONAL DE DIREITOS HUMANOS. Princípios de Yogyakarta: princípios sobre a aplicação da legislação internacional de direitos humanos em relação à orientação sexual e identidade de gênero. Indonésia: Universidade Gadjah Mada, 2006. Disponível em:

http://www.dhnet.org.br/direitos/sos/gays/principios de yogyakarta.pdf. Acesso em: 19 nov. 2020.

DARDOT, Pierre; LAVAL, Christian. A nova razão do mundo: ensaio sobre a sociedade neoliberal. trad. Mariana Echalar. São Paulo: Boitempo, 2016.

FRASER, Nancy. Da redistribuição ao reconhecimento? Dilemas da justiça numa era "póssocialista". Trad. Júlia Assis Simões. Cadernos de Campo, v. 15, n. 14-15, p. 231-239, 2006. Disponível em:

https://www.revistas.usp.br/cadernosdecampo/article/download/50109/54229. Acesso em: 09 fev. 2021.

FRASER, Nancy. A justiça social na globalização: redistribuição, reconhecimento e participação. Trad. Teresa Tavares. Revista Crítica de Ciências Sociais, n. 63, p. 07-20, 1 out. 2002. Disponível em: https://journals.openedition.org/rccs/1250. Acesso em: 09 fev. 2021.

FRIAS, Lincoln; LOPES, Nairo. Considerações sobre o conceito de dignidade humana. Revista Direito GV, v. 11, n. 2, p. 649-670, dez. 2015.Disponível em:

https://www.scielo.br/scielo.php?pid=S1808-

24322015000200649\&script=sci arttext\&tlng=pt. Acesso em: 09 fev. 2021.

BeltRAMELLI NETO, Silvio. Conteúdo material e culturalmente inclusivo do Princípio da Dignidade da Pessoa Humana. Revista Jurídica Trabalho e Desenvolvimento Humano, Campinas, v. 4, p. 1-42, 2021. 
GOMES, Camilla de Magalhães. Os sujeitos do performativo jurídico - relendo a dignidade da pessoa humana nos marcos de gênero e raça. Revista Direito e Práxis, v. 10, n. 2, p. 871905, jun. 2019. Disponível em: https://www.scielo.br/scielo.php?pid=S217989662019000200871\&script=sci arttext\&tlng=pt. Acesso em: 09 fev. 2021.

HEGEL, G. W. Princípios da Filosofia do Direito. Trad. Orlando Vitorino. São Paulo: Martins Fontes, 1997.

HONNETH, Axel. Luta por reconhecimento: a gramática moral dos conflitos sociais. Trad. Luiz Sérgio Repa. São Paulo: Ed. 34, 2011.

KANT, Immanuel. Fundamentação da metafísica dos costumes e outros escritos. Trad. Leopoldo Holzbach. São Paulo: Martin Claret, 2005.

LAUXEN, Elis Cristina Uhry; BARRETTO, Vicente de Paulo. A (re)construção da ideia de dignidade humana. Revista Quaestio luris, v. 11, n. 1, p. 67-88, 11 jan. 2018. Disponível em: https://www.e-publicacoes.ueri.br/index.php/quaestioiuris/article/view/22980. Acesso em: 09 fev. 2021.

MALUSCHKE, Günther. A dignidade humana como princípio ético-jurídico. NOMOS - Revista do Curso de Mestrado da UFC, v. 37, n. 1, p. 95-117, jun. 2017. Disponível em: http://repositorio.ufc.br/handle/riufc/28860. Acesso em: 09 fev. 2021.

MARX, Karl; ENGELS, Friedrich. A ideologia alemã. Trad. Álvaro Pina. São Paulo: Expressão Popular, 2009.

MENDONÇA, Samuel. Objeções à igualdade e à democracia: a diferença como base da educação aristocrática. ETD - Educação Temática Digital, v. 14, n. 1, p. 332-350, 2012. Disponível em: https://www.ssoar.info/ssoar/handle/document/31312. Acesso em: 09 fev. 2021.

NIETZSCHE, Friedrich. Escritos sobre Política. Trad. Noéli Correia de Melo Sobrinho. São Paulo, SP: Loyola, 2007.

NIETZSCHE, Friedrich. Genealogia da moral: uma polêmica. Trad. Paulo César de Souza. São Paulo: Companhia das Letras, 2009.

RAMOS, André de Carvalho. Curso de Direitos Humanos. 7. ed. São Paulo: Saraiva Educação, 2020.

ROUSSEAU, Jean-Jaques. Do contrato social. Trad. Pietro Nassetti. São Paulo: Martin Claret, 2004. 
Revista Jurídica Trabalho e Desenvolvimento Humano

Procuradoria Regional do Trabalho da 15a Região

SANTOS, Boaventura de Sousa. The resilience of abyssal exclusions in our societies: toward a post-abyssal law. Tilburg Law Review, v. 22, n. 1-2, p. 237-258, 2017. Disponível em:

https://brill.com/view/journals/tilr/22/1-2/article-p237 237.xml. Acesso em: 09 fev. 2021.

SANTOS, Boaventura de Sousa. Pela mão de Alice: o social e o político na pós-modernidade. 14. ed. São Paulo: Cortez, 2013.

SANTOS, Boaventura de Sousa. A gramática do tempo: para uma nova cultura política. 2. ed. Porto: Edições Afrontamento, 2010.

SANTOS, Boaventura de Sousa. Do pós-moderno ao pós-colonial. E para além de um e de outro. Travessias, n. 6/7, p. 15-36, 2008.

SANTOS, Boaventura de Sousa. A crítica da razão indolente: contra o desperdício da experiência. 2 ed. Porto: Edições Afrontamento, 2002.

SARLET, Ingo W. Notas sobre a dignidade da pessoa humana na jurisprudência do STF. In SARMENTO, Daniel; SARLET, Ingo W. (Coord.). Direitos Fundamentais no Supremo Tribunal Federal: balanço e crítica. Rio de Janeiro: Lumen Juris, 2011.

SARLET, Ingo W. Dignidade da pessoa humana e direitos fundamentais na Constituição Federal de 1988. 4. ed. Porto Alegre: Livr. do Advogado, 2006.

SARLET, Ingo W.; FIGUEIREDO, Mariana Filchtiner. Reserva do possível, mínimo existencial e direito à saúde. Revista Brasileira de Direitos Fundamentais \& Justiça, v. 1, n. 1, p. 171-213, 2007. Disponível em: http://dfj.emnuvens.com.br/dfj/article/view/590. Acesso em: 09 fev. 2021.

SARMENTO, Daniel. Dignidade da pessoa humana: conteúdo, trajetórias e metodologia. 2. ed. Belo Horizonte: Fórum, 2020.

SEN, Amartya. Desenvolvimento como liberdade. Trad. Laura Teixeira Motta. São Paulo: Companhia das Letras, 2010.

SEN, Amartya. Sobre ética e economia. Trad. Laura Teixeira Motta. São Paulo: Companhia das Letras, 1999.

SILVA, José Afonso da. A dignidade da pessoa humana com valor supremo da democracia. Revista de direito administrativo, v. 212, p. 89-94, 1998. Disponível em:

http://bibliotecadigital.fgv.br/ojs/index.php/rda/article/download/47169/45637. Acesso em: 09 fev. 2021.

UNITED NATIONS. COMMITTEE ON ECONOMIC, SOCIAL AND CULTURAL RIGHTS. General comment No. 3: The nature of States parties' obligations (art. 2, para. 1, of the Covenant). 
Genebra, 1990. Disponível em:

https://tbinternet.ohchr.org/Treaties/CESCR/Shared\%20Documents/1 Global/INT CESCR G EC 4758 E.doc. Acesso em: 30 out. 2020.

UNITED NATIONS. COMMITTEE ON ECONOMIC, SOCIAL AND CULTURAL RIGHTS. General comment No. 20: Non-discrimination in economic, social and cultural rights (art. 2, para. 2, of the International Covenant on Economic, Social and Cultural Rights). Geneve, 2009. Disponível em:

https://tbinternet.ohchr.org/ layouts/15/treatybodyexternal/Download.aspx?symbolno=E\% 2fC.12\%2fGC\%2f20\&Lang=en. Acesso em: 30 out. 2020. 